NBER WORKING PAPER SERIES

\title{
PUBLIC R\&D POLICIES AND COST BEHAVIOR OF THE US MANUFACTURING INDUSTRIES
}

Theofanis P. Mamuneas

M. Ishaq Nadiri

Working Paper No. 5059

\section{NATIONAL BUREAU OF ECONOMIC RESEARCH 1050 Massachusetts Avenue \\ Cambridge, MA 02138 \\ March 1995}

\begin{abstract}
The authors would like to thank Bhaswar Mukhopadhyay and Richand Simon for their help in preparing this manuscript and two referees for very constructive and helpful comments. We also acknowledge support from the C.V. Starr Center for Applied Economics of New York University. This paper is part of NBER's research programs in Growth and Productivity. Any opinions expressed are those of the authors and not those of the National Bureau of Economic Research.

(C) 1995 by Theofanis P. Mamuneas and M. Ishaq Nadiri. All rights reserved. Short sections of text, not to exceed two paragraphs, may be quoted without explicit permission provided that full credit, including (C) notice, is given to the source.
\end{abstract}




\title{
PUBLIC R\&D POLICIES AND COST BEHAVIOR OF THE US \\ MANUFACTURING INDUSTRIES
}

\begin{abstract}
This paper estimates and evaluates the contributions of R\&D tax incentives and publicly financed $R \& D$ investment policies in promoting growth of output and privately funded $R \& D$ investment in US manufacturing industries. Publicly financed R\&D induces cost savings but crowds out privately-financed $R \& D$ investment while the incremental $R \& D$ tax credit and immediate deductibility provision of $R \& D$ expenditures have a significant impact on privately financed $R \& D$ investment. The optimal mix of both instruments is an important element for sustaining a balanced growth in output and productivity in the manufacturing sector.
\end{abstract}

Theofanis P. Mamuneas Department of Economics New York University 269 Mercer Street, 7th Floor New York, NY 10003
M. Ishaq Nadiri Department of Economics New York University 269 Mercer Street, 7th Floor New York, NY 10003 and NBER 


\section{Introduction ${ }^{1}$}

An important characteristic of R\&D investment which distinguishes it from other types of investment is that its output has the properties of public goods: It can be considered at least partially non-excludable and nonrivalrous (see Arrow (1962), Spence (1984), and Romer (1990)). Indeed, the empirical literature provides evidence that not only is the rate of return of privately-funded $R \& D$ very high compared to that of investment in physical capital, but, more importantly, its social rate of return is several times higher than its private rate of return (see, for instance, Cohen and Levin (1989), Griliches $(1979,1991)$, Mohnen $(1989,1990)$ and Nadiri $(1980,1993))$ This suggests that there are substantial externalities associated with R\&D investment, and therefore privately-financed R\&D is suboptimal and may require the direct or indirect support of government.

Theoretically, there are many different ways to deal with market failure associated with externalities. ${ }^{2}$ For instance, externality-generating activities can be encouraged by providing subsidies, by granting producers property rights and charging differential prices for their use by others, by allowing firms to internalize the externality and, finally, by having the government engage directly in externality-generating activities. Indeed, in the postwar period, the US government has followed a combination of these policies: establishment of innovators' property rights through the patent system, encouragement of firms to form joint R\&D ventures, direct investment of R\&D through R\&D contracts with companies, universities and other nonprofit institutions, and lastly, tax incentives for company-financed R\&D.

The objective of this paper is to evaluate the contributions of tax incentives and public financing of R\&D investment policies in promoting growth of output and productivity of the US manufacturing industries. First, we 
provide econometric evidence of the effects of R\&D tax policies in stimulating privately-funded R\&D. ${ }^{3}$ We are particularly interested in calculating the effect of $R \& D$ tax credit and of treating $R \& D$ expenditures as an operating expense rather than capital expenditures. To put it differently, we are interested in measuring how much private $R \& D$ investment would have fallen if the R\&D tax credit were abolished and if $R \& D$ expenditures were treated as capital expenditures similar to the expenditures on plant and equipment. Second, we investigate the existence and extent of the spillover effects of publicly-funded $R \& D$ capital on the cost structure of manufacturing industries at a disaggregated level.

A number of studies have examined the effect of industry-spectfic, publicly-financed $R \& D$ granted to firms in speciflc industries. The empirical results have been thus far inconclusive." In contrast, however, we are interested in evaluating the effects on growth and productivity of publicly financed $R \& D$ performed within the industries (internal $R \& D$ ) as well as the effects of publicly financed $R \& D$ performed in other industries and non-profit institutions (external R\&D). This type of spillover effect of publiclyfinanced R\&D has not, to our knowledge, yet been studied. Finally, we evaluate these policies by estimating (i) a social benefit-cost ratio of publicly-financed $R \& D$, and (ii) the additional privately-funded R\&D expenditures generated by the $R \& D$ tax policies relative to the foregone government tax revenues.

To achieve these objectives, we estimate a cost function dual to a production function where, except for the traditional inputs, the rental price of company-financed R\&D capital, and the capital of publicly-financed R\&D explicitly enter into the cost function. Our results suggest that, on the one hand, publicly-financed R\&D induces cost savings but crowds privately-financed 
$R \& D$ investment. On the other hand, the incremental R\&D tax credit introduced In 1981 and the immediate deductibility provision of R\&D expenditures, especially the latter, have a substantial inducement effect on private R\&D expenditures in the manufacturing sector.

\section{The Yodel and Empirical Implementation}

The theoretical basis of our model is the standard neoclassical production function augmented to include three R\&D capital stocks, one financed by the industry and two publicly financed R\&D, one performed within the industry and the other outside, which may capture potential spillover benefits from government-financed $R \& D$ activities. We assume that firms within an industry minimize their post-tax long-run cost of production subject to the production function, and that the two types of publicly-financed R\&D are unpaid inputs of production. The post-tax long-run cost function of an industry at time $t$ is glven by

$$
c=c(p, y, G ; t)
$$

where $p$ is a vector of the after-tax rental price of inputs, $y$ is the Industry's output, and $G$ is the vector of publicly financed R\&D capital stocks.

To estimate the productive effects of government's R\&D tax pollcy, we need to know the elasticity of company-financed $R \& D$ with respect to Its own price, and the cross-price elasticities of all other inputs with respect to the price of R\&D, as well as the effect of tax incentive on the after-tax rental price of company-financed R\&D. A convenient feature of duality theory is that the second derivatives of cost function with respect to input prices, 1.e., the Bordered Hessian matrix $C_{1 j}-\left(\partial^{2} C / \partial p_{1} p_{j}\right)$, correspond to the input demand price 
derivatives (see Diewert (1974) or Varian (1984)). The effect of tax incentives on the input demands can therefore be calculated in a straightforward manner by estimating a cost function like (1), and by knowing the effect of tax incentives on the rental price of company-financed $R \& D$.

In addition, the effect of publicly-financed R\&D stocks can be estimated by observing that its derivative of cost, $\partial C / \partial G(\kappa 0)$, corresponds to the cost change due to an additional unit of public R\&D. If the sign is negative, a positive externality exists, while a positive sign indicates the existence of a negative externality. The marginal benefits or marginal willingness to pay functions for the publicly financed $R \& D$ stocks can be defined as

$$
b_{s}(P, y, G ; t)--\partial C / \partial G_{s} .
$$

$b_{s}$ measures the benefit, in terms of cost reduction, gained by an industry due to an increase of a unit of government-financed $R \& D$ capital (see Diewert (1986)).

We specify a translog cost function, assuming that industry $h$ employs four private inputs, namely labor, intermediate inputs, physical capital (structures plus equipment), company-financed R\&D capital, and two publiclyfinanced R\&D capital stocks. The post-tax cost function is given by

$$
\begin{aligned}
& \ln C^{h} / P_{m}^{h}=\beta_{0}+\alpha_{0}^{h} D^{h}+\left(\beta_{Y}+\alpha_{Y}^{h} D^{h}\right) \ln Y^{h} \\
& +\sum_{1}\left(\beta_{1}+\alpha_{1}^{h} D^{h}\right) \ln w_{i}^{h}+\beta_{T} t+\sum_{j} \beta_{Y_{1}} \ln Y^{h} \ln w_{i}^{h} \\
& +\beta_{Y T} \ln Y^{h} t+\sum_{i} \sum_{j} \beta_{i j} \ln w_{i}^{h} \ln w_{j}^{h}+\sum_{j} \beta_{i I} \ln w_{i}^{h} t \\
& +\sum_{s}\left(\phi_{s}+\gamma^{h} D^{h}+\phi_{Y s} \ln Y^{h}+\sum_{1} \phi_{1 s} \ln w_{1}^{h}+\phi_{I s} t\right) \ln G_{s} \text {. } \\
& \text { inj - L, K, R; } \\
& s-I, E \text {; } \\
& h-1, \ldots, n \text {, }
\end{aligned}
$$


where $C, w, Y, t, G, D$ denote, respectively, total production cost $\left(C-\sum P_{J}\right.$ $x_{j}$ ), the vector of relative input prices with respect to the price of materials, $P_{M}\left(w_{1}-P_{1} / P_{M}\right)$, output, a time shift variable representing exogenous technological change or other time-specific effects experienced by the industries, the two publicly-financed R\&D capital, and a set of dumny variables capturing industry specific effects. The subscripts $i$ and $j$ denote the own inputs, and $h$ the industries; the subscripts $M, L, K, R$, denote, respectively, the intermediate inputs, labor, physical capital, and the industries' privately-financed R\&D capital. The two types of publicly financed R\&D capital stocks are distinguished by the subscript $s . G_{I}$ refers to publicly financed $R \& D$ performed internally in the industry and $G_{E}$ refers to publicly financed R\&D performed outside of the industry in question. The parameters \& capture the externalities generated from the public R\&D capital. The existence of parameters $\alpha$ and $\gamma$ enables us to capture industry specific effects as deviations from the $\beta$ and $\phi$ parameters. The coefficlents of the dummy variables have been normalized such that for the industry $n, \alpha^{n}-\gamma^{n}-$ 0 .

Applying Shephard's lemma (Diewert (1974)), the following share equations are obtained:

$$
S_{i}^{h}-\beta_{1}+\alpha_{1}^{h} D^{h}+\beta_{Y 1} \ln Y^{h}+\beta_{1 j} \ln w_{j}^{h}+\beta_{1 t} t+\sum_{s} \phi_{1 s} \ln G_{s},
$$

i $-\mathrm{L}, \mathrm{K}, \mathrm{R}$;

$s-I, E$;

$h-1, \ldots, n$,

where $s_{1}^{h}-p_{1}^{h} x_{1}^{h} / c^{h}$. The share of the input used for the normalization is calculated by $s_{M}^{h}-1-\sum_{1} s_{1}^{h}$. Shares are affected by publicly-financed $R \& D$ capital stocks and the parameter $\phi_{1 \mathrm{~s}}$ determines the factor bias effect associated with these stocks in each industry. 
The Hessian matrix $\left(\partial^{2} C / \partial p_{1} \partial p_{j}\right)$ should be negative semi-definite in order for the cost function to be concave in input prices. In addition, for the cost function to be convex in $G$, the matrix $\left(\partial^{2} C / \partial G_{I} G_{E}\right)$ should be positive semi-definite. Note that in order for the technology set to be convex, all of the above conditions should be satisfied (see Diewert (1986)). Furthermore, in order for the spillovers to have a meaningful context, the cost function should be non-increasing in G. Finally, the cost function must be nondecreasing in output, and linear homogeneous in Input prices (see Jorgenson (1986)). The last condition is automatically satisfied, since we have normalized with the price of intermediate inputs.

The model is applied in a sample of twelve manufacturing industries, plus three groups of industries which were aggregated because the National Science Foundation does not provide R\&D data individually. The sample covers all industries of the manufacturing sector, which are reported in table 1 . The estimation period covers the years 1956 to 1988. A detailed description and construction of the variables of the model are reported in the appendix." Assuming that the errors attached to equations (3) and (4) are optimizing errors, they are jointly normally distributed with zero expected value, and with a positive definite symmetric covariance matrix. The data on industries are pooled and the estimation is carried out with the full information maximum likel ihood estimator.

Our estimation results are reported in table $2 .^{6}$ The Individual parameter estimates have a high t-statistic, and $R^{2}$ of the estimating equations are high. The standard errors of the regressions are quite low, indicating a good fit. The parameters associated with government-financed R\&D capital stocks are statistically significant, which implies that there are Indeed spillovers associated with publicly-funded R\&D capital. In addition, 
the coefficients of industry dumny variables (not reported) were also jointly statistically significant, implying interindustry differences in technology.

A number of hypothesis tests were carried out based on the likelihood ratio test. These tests are reported in table 3. First, we tested whether the production technology across industries is the same or whether industries have the same technology only for the private Inputs. These hypotheses are rejected as indicated by the chi-square statistics shown in the first and second rows of table 3 . Second, we tested whether the cost function is Independent of publicly-financed $R \& D$. We reestimated the model by setting all publicly financed $R \& D$ parameters equal to zero, only the "internal public" R\&D parameters equal to zero and finally the "external public" R\&D parameters equal to zero. The $\log$ of likelihood function as well the chi-square statistic of these tests are reported in the third, fourth and fifth rows of table 3 respectively. These hypotheses were also decisively rejected. We also tested that industries do not experience exogenous technological shocks. This hypothesis was also clearly rejected (see table 3, sixth row). Finally, we parametrize differently our model to test the hypothesis that the marginal benefits of the two types of public capital are the same. Instead of the two public capital variables being entered separately in the cost function we specify one publicly financed $R \& D$ variable by $\ln \left(G_{E}+(1+w) G_{I}\right)$ which can be approximated by $\ln G_{0}+\omega \pi_{I}$, where $G_{0}-G_{E}+G_{I}$ and $\pi_{I}-G_{I} / G_{0}$. The null hypothesis is that the marginal effects on cost are equal, ie., $\omega-0$. This hypothesis is also rejected with an estimated value of $\omega$ equal of 3.71 (std. err. -.485$)$.

The Effects of R\&D Tax Policy on Cost Structure The federal government, recognizing the importance of $R \& D$ investment for 
economic growth and international competitiveness, has historically treated $R \& D$ investment more favorably than other kinds of investments. The federal government basically uses two kinds of tax policy instruments to stimulate R\&D expenditures. One, in place since 1954, is the immediate deductibility provision of company-financed $R \& D$ expenditures, and the other is the direct R\&D tax credit introduced by the Economic Recovery Tax Act (ERTA) of 1981. The ERTA, in addition to the introduction of the Accelerated Recovery System (ARCS) for investment in plant and equipment, introduced an incremental R\&D tax credit for qualified research expenditures. Firms were eligible to claim either 258 credit if their $R \& D$ expenditures exceeded the average of $R \& D$ spending of the three previous years or half of the credit if they were above twice the base. This credit was initially intended to expire at the end of 1985, but was renewed at a rate of 208 for two additional years in the Tax Reform Act of 1986 (TRA).?

In order to see the effect of these two R\&D tax incentives on the price of $R \& D$, assume that a firm incurs $\$ 1$ of $R \& D$ expenditures in excess of 1 ts R\&D expenditures in the past three years. With an incremental tax credit of 258 , this means that the cost to the firm will be reduced by $\$ 1 \times .25-\$ .25$. However, the $\$ 1$ increase in $R \& D$ expenditures decreases the incremental $R \& D$ tax credit for the next three years by $\$ .33 \times .25-\$ .083$ for each year, since the credit is based on the average of the R\&D expenditures of the three previous years. Thus with a discount rate of 10 the net tax reduction of a $\$ 1$ increase in R\&D expenditures is $\$ .25-\left(\sum_{1-1}^{3} \$ .083 /(1+.10)^{1}\right)-.045 \$$, and the actual post-tax cost of the expenditures is $\$ 1-\$ .045-\$ .955$.

Consider now the effect of the immediate deductibility provision of R\&D expenditures. Suppose that the corporate income tax rate is 468 ; then the tax reduction is $\$ .46$, and the after-tax cost of $R \& D$ expenditures $\$ 1-\$ .46-$ 
\$.54. Combining these two incentives, the after-tax cost of $\$ 1$ of $R \& D$ expenditures is $\$ 1-\$ .46-\$ .045-\$ .495$, i.e., about 50 less than its before $\operatorname{tax}$ cost.

In order for the firms to benefit from the tax incentives, they must have sufficient taxable income. In addition, in the case of incremental R\&D tax, Eisner et. al (1984) have estimated that in 1981 and 1982 about 258 and 358 , respectively, of the firms in the manufacturing sector did not claim the incremental $R \& D$ tax credit either because they did not increase their R\&D expenditures over the base or they did not have sufficient federal income tax liabilities. Also note that the incremental character of the credit in some cases might even make the effective rate negative (see, Eisner et al. (1984) and Hall (1992)). In the absence of information, we assume that the firms in our sample of industries have enough tax llabilities, and that the increase of their R\&D expenditures was greater than the base but less than twice the base.

Under the above assumptions, let $u_{c}$ be the corporate income tax rate, 5 the incremerital R\&D tax credit, and $\lambda$ a parameter taking values of 1 if there is immediate expensing of R\&D expenditures, but values less than 1 otherwise. ${ }^{8}$ The after-tax cost of R\&D expenditures is given by $q_{R}\left(1-\lambda u_{c}-\nu \zeta\right)$, where $q_{R}$ is the acquisition price, $\nu-\left(1-\sum_{1-1}^{3} \cdot 33 /(1+r)^{1}\right)$ and $r$ is the discount rate. ${ }^{8}$ Table 4 shows the after-tax cost of $\$ 1$ R\&D expenditures for the period 1981 to 1988 . The average after-tax cost of $\$ 1$ R\&D expenditures for this period is about $\$ .55$, where the contributions of immediate expensing and the incremental R\&D tax credit are about .42 and .038 respectively.

Let the after-tax rental price of R\&D capital services $\left(P_{R}\right)$ be defined by the equality between the post-tax cost of acquisition and the present value of future rentals (see for instance Hall and Jorgenson (1967)), then the post-tax rental price of company-financed R\&D capital is given by 


$$
p_{R}-q_{R}\left(r+\delta_{R}\right)\left(1-\lambda u_{c}-\nu 5\right) \text {, }
$$

where $r$ is the discount rate and $\delta_{R}$ is the depreciation rate of company-

financed R\&D capital. For a given level of output, the effect of a change in tax incentives ( $T$ ) on the demand of R\&D capital stock and on the other inputs is given by

$$
\eta_{j I}^{h}-\partial \ln x_{j} / \partial \ln T-\epsilon_{j R}^{h}\left(\partial \ln P_{R} / \partial \ln T\right)
$$

$T=5, \lambda$

$j=L, K, R, M$,

where $\epsilon_{\mathfrak{J R}}^{\mathrm{h}}$ is the price elasticity of input demands with respect to the rental price of $R \& D$ capital and $\left(\partial \ln p_{R} / \partial \ln T\right)$ is the elasticity of the rental price of $R \& D$ capital with respect to a change in tax incentives and is equal to either

$$
\operatorname{aln} p_{R} / \operatorname{aln} 5--25 /\left(1-\lambda u_{c}-\nu 5\right)
$$

for a change in incremental R\&D credit or

$$
\partial \ln p_{R} / \partial \ln \lambda-\lambda u_{c} /\left(1-\lambda u_{c}-\nu 5\right)
$$

for a change in immediate expensing.

The conditional input demand price elasticities are reported in table 5. The price elasticities of the input demands are calculated by $\epsilon_{1 j}^{h}-s_{j}^{h} \sigma_{1 j}^{h}$, where $\sigma_{1 j}$ are the Allen elasticities of substitution and under our cost function specification are equal to $\sigma_{1 j}^{\mathrm{h}}-\left(\beta_{1 j}+s_{1}^{\mathrm{h}} s_{\mathrm{j}}^{\mathrm{h}}\right) / s_{1}^{\mathrm{h}} s_{\mathrm{j}}^{\mathrm{h}}$ and $\sigma_{11}^{\mathrm{h}}-$ $\left(s_{1}^{h 2}-s_{1}^{h}\right) / s_{1}^{h 2}$. The diagonal elements in each panel of industries correspond to own price elasticities. One obvious pattern that emerges from this table is that the own price elasticities of labor, physical capital and 
intermediate inputs vary from one industry to another. Conversely, the own price elasticity of company-financed R\&D capital does not vary much from industry to industry. ${ }^{10}$ The own price elasticity of private R\&D capital ranges from -1 in the three aggregates textile and apparel (40), lumber, wood products and furniture (41) and other manufacturing (42) to -0.94 in scientific instruments (38). The company-financed R\&D elasticity estimated in this study is in the middle range of own price elasticities of R\&D reported in the literature. Hines (1991) has estimated a price elasticity of companyfinanced R\&D about -1.2, Hall (1992) about -1, while Nadiri and Prucha (1994b), Bernstein and Nadiri (1989) have reported a price elasticity of total R\&D (company - plus publicly-financed) of about - 0.4 to -0.5 . Our estimates are closer to Hall (1992) and Hines's (1991). The difference between our estimates of own price elasticity of company-financed R\&D and the estimates of Bernstein and Nadiri and Nadiri and Prucha can be explained by the fact that the elasticities estimated by those authors pertain to total R\&D performed by the industry, ie., company-financed as well as publicly-financed, and thus respond less to price changes.

Another interesting observation that emerges from table 5 is that companyfinanced R\&D capital and physical capital are substitutes. In high R\&D intensive industries, however, this relation is rather weak. It also seems that a change in the price of company-financed R\&D affects physical capital relatively less than a change in the price of physical capital affects company-financed R\&D capital: This has a very important implication for public policy since the tax policy for structures and equipment will have significant indirect effects on the R\&D investment. Cordes (1984), for instance, has argued that the Accelerated Recovery System, introduced in 1981 for plant and equipment investment, has reduced the relative price of physical 
capital in comparison to that of $R \& D$ capital. Thus the introduction of an incremental $R \& D$ tax credit was necessary to restore to some degree the incentives for R\&D investment. Finally, while company-financed R\&D is a substitute for labor, it is a complement of intermediate inputs in low R\&D intensive industries, but a weak substitute in high-tech industries, such as chemical (28), machinery (35), electrical equipment (36), transportation equipment (37), and scientific instruments (38).

The average elasticities of cost, labor, physical capital, R\&D capital and intermediate inputs with respect to incremental $R \& D$ tax credit are reported in table $6 .^{11}$ This table has been constructed by multiplying the input price elasticities by the percentage change of rental R\&D price due to a change in the incremental R\&D tax credit. Similarly, in table 7, we present the average elasticities of the cost and input demands with respect to the rate of immediate expensing of R\&D expenditures. Clearly, a change in the rate of expensing has a much larger effect, by almost ten times, than a change in incremental R\&D tax credit. This is because the immediate deduction of R\&D expenditures constitutes about 908 to 968 of the reduction of the cost of R\&D, while the incremental R\&D tax credit constitutes the rest. The effect of the incremental R\&D tax credit is small but nevertheless significant. Both effects are relatively larger in the low $R \& D$ intensive industries than in high-tech industries, reflecting the fact that industries with a long tradition of R\&D investment respond less to the cost changes of R\&D investment This is consistent with the evidence from the tax forms of 1981,1982 and 1983, (see Cordes (1988, 1989)) showing that, after the introduction of R\&D tax credit, the high-tech manufacturing industries reported smaller increases in the R\&D expenditures than the other manufacturing industries.

Based on our estimates, the incremental R\&D tax credit had generated about 
$\$ 2.5$ billion dollars (on average) of additional R\&D expenditures per year at the manufacturing sector for the period 1981-1988. This estimate is consistent with that reported by Baily and Lawrence (1992) and Hall (1992). If it is adjusted with the eligibility ratio of about .63 (see Eisner et al. (1984)), the R\&D credit has stimulated about $\$ 1.6$ billion dollars of additional R\&D expenditures per year. ${ }^{12}$ However, it should be noted that this estimate might be blas upwards since there is evidence that many firms redefined activities as $R \& D$, after the introduction of $R \& D$ tax credit as noted by Mansfield (1994).

Suppose now that the government, instead of allowing the immediate deductibility of $R \& D$ investment, allows only the economic depreciation of $R \& D$ expenditures to be deducted from current income. With a discount rate and depreciation rate of 108 (see footnote 8 ), this implies that the value of the parameter $\lambda$ is .5 , and will account on average for a roughly 358 decline of R\&D expenditures, or about $\$ 16$ billion dollars per year for the manufacturing sector as a whole. Combining this estimate with the additional expenditures stimulated by the $R \& D$ tax credit, government tax incentives would generate about $\$ 18$ billion dollars per year of additional R\&D expenditures. This amounts to approximately 408 of the total privately-financed R\&D of the entire manufacturing sector. Moreover, if one takes into account that government directly finances about 308 of total R\&D performed in the manufacturing sector, the tremendous support of $R \& D$ activity by the federal government is quite clear.

\section{The Effects of Publicly-Funded R\&D on the Cost Structure}

An increase of publicly-funded $R \& D$ has a significant effect on the cost of industries if, as has been discussed, the derivatives of cost function with 
respect to publicly-financed $R \& D$ capital stocks are different from zero. Taking the derivative of cost function with respect to internally and externally performed publicly financed $R \& D$, the elasticity of cost is given by $\eta_{C s}^{h}-\partial \ln C^{h} / \partial \ln G_{s}^{h}-\phi_{3}+\gamma^{h} D^{h}+\phi_{Y s} \ln Y^{h}+\sum_{1} \phi_{1 s} \ln w_{1}^{h}+\phi_{T s} t$

$$
\begin{aligned}
& s=\mathrm{I}, \mathrm{E} ; \\
& \mathrm{h}=1, \ldots \mathrm{n} .
\end{aligned}
$$

In addition, a change of publicly-financed R\&D affects not only the cost function, but also the demand for inputs. The elasticity of the inputs' demand is given by

$$
\eta_{j s}^{h}-\partial \ln x_{j}^{h} / \partial \ln G_{s}^{h}-\eta_{c_{s}}^{h}+\left(1 / s_{j}^{h}\right) \phi_{1 s}
$$

$j-L, K, R, M$;

$s=I, E$;

$\mathrm{h}-1, \ldots, \mathrm{n}$.

If (8) is positive, negative or zero, it implies that the publicly-financed capital $s$ and the $j$ th private input are complements, substitutes, or independent, respectively.

The effects of internal and external publicly-financed $R \& D$ on the cost and input demands are reported in table 8 . In addition we have calculated the effect of total publicly financed R\&D, assuming that the distribution of publicly financed R\&D investment across industries remains the same. ${ }^{13}$ our results support the hypothesis that there is a positive externality from publicly-financed R\&D. This finding is in contrast with other studies which usually report insignificant or weak effects on productivity from publicly financed R\&D performed within an industry (see for instance Griliches (1980, 1986), and Terleckyj (1974, 1984)). The total effect on cost is significant in all industries in the manufacturing sector except in primary metals (33). 
A percentage change in publicly financed $R \& D$ performed outside of the industry has significant and much higher percentage effect on cost than the publicly financed R\&D carried out internally, with the exception in primary metals industry (33) where the cost elasticity of external public R\&D is statistically insignificant. However, if we compare the relative marginal cost reductions $\left(d C^{h} / d G_{s}^{h}-\eta_{C_{s}}^{h} C^{h} / G_{s}^{h}\right)$ of internal and external public $R \& D$, the marginal cost reduction of internal publicly financed $R \& D$ is substantially higher than the external one. For instance, in chemical industry (28), in 1982, the cost elasticity of internal publicly financed $R \& D$ is $37 \%$ as large as the cost elasticity of external publicly financed R\&D; But since the external publicly financed $R \& D$ is almost 73 times larger than the internal publicly financed $R \& D$, the marginal cost reduction of internal publicly financed $R \& D$ is about 27 times larger than the external publicly financed R\&D. The same is true for all the other industries, with the relative internal public $R \& D$ marginal cost reduction being larger than the marginal cost reduction of external publicly financed $R \& D$ from 2 times in electrical equipment (36) and transportation equipment (37) to 142 times in stone, clay and glass products (32).

In all industries the labor and intermediate inputs are substitutes with the internal and external publicly-financed $R \& D$ capital. The effect of internal and external publicly-financed R\&D capital on physical capital varies across industries in terms of the magnitude as well as its direction. Internal publicly-financed R\&D and physical capital are substitutes in all industries with stronger substitution effect in high-tech industries, like machinery (35), electrical equipment (36), and scientific instruments (38). On the other hand physical capital is a weak complement to external publicly financed $R \& D$ in high tech industries or independent in low tech industries. 
Two hypotheses have been advanced between the relationship of publiclyfinanced and privately-financed R\&D performed by the industries. One supports the idea that new scientific knowledge resulting from government financed $R \& D$ expands firms' basic knowledge and thus induces the firms own R\&D (Goldberg (1979), Jaffe (1989), Levin and Reiss (1984), Levy and Terleckyf (1983), Link (1982), Nadiri (1980) and Scott (1984)); the other suggests that publiclyfinanced and company-financed R\&D are substitutes, because either the output of public R\&D activity is internalized by the firms, or the publicly-financed R\&D performed by the firms causes the firms to reach their full R\&D capacity (Carmichael (1981), Lichtenberg (1984, 1988) and Nadirf (1980)). Our estimates seem to support the former hypothesis for the internally performed publicly financed $R \& D$, and the latter hypothesis for the externally performed publicly financed R\&D. Indeed, company financed R\&D and "inside" publicly financed R\&D is a complement in low R\&D intensive industries and independent in hIgh R\&D Intensive industries. On the other hand, company financed R\&D and "outside" publicly financed $R \& D$ are substitutes, especially in the low R\&D intensive industries, where the effect is more than one.

Overall, our estimates suggest that the spillover effect of publiclyfinanced $R \& D$ reduces the cost to industries and thus enhances their productivity growth. However, it seems that the overall effect of publiclyfinanced $R \& D$ crowds out company-financed $R \& D$ in all industries. Indeed, in low R\&D intensive industries the crowding-out effect of publicly-financed R\&D is more than one to one, while in high-tech industries publicly and privatelyfinanced R\&D are weak substicutes, as for instance in machinery (35), electrical equipment (36), transportation equipment (37) and scientific instruments (38). 


\section{The Effectiveness of Publicly-Financed R\&D and R\&D Tax Policy}

The objective of this section is to evaluate the effectiveness of tax policles and the federal government's R\&D expenditures. As far as the incremental R\&D tax credit is concerned, this can be done by measuring the additional R\&D expenditures generated relative to foregone tax revenues. For publicly-financed $R \& D$, this can be done by comparing the social benefits and costs of publicly-financed $R \& D$ capital.

There is some disagreement among economists about the effectiveness of R\&D tax credit. For instance, Mansfield $(1985,1986)$ has estimated that the additional R\&D expenditures per dollar cost to the government ranges between $\$ .3$ to $\$ .4$. Baily and Lawrence (1992) have estimated it to be about $\$ 1$ to \$1.4. About the same estimates as Baily's are provided by Hines (1991), while Hall (1992) estimates that the ratio is about 2. These differences in estimates are basically due to different price elasticities of R\&D employed by the authors. Noting that the tax incentives are subsidies to production, for a given output the resulting reduction in industry costs is equal to the loss of government revenue. Thus, we can calculate the ratio of additional R\&D capital services over the foregone government revenue by

$$
r_{S}=\sum_{h} \eta_{R S}^{h} p_{R}^{h} x_{R}^{h} / \sum_{h} \eta_{C S}^{h} C^{h} .
$$

where the numerator is the sum of additional R\&D capital services over all industries and the denominator is the foregone government revenues. Our estimate implies an average of additional $R \& D$ per dollar of government revenue lost to be about .95 for the period 1981 to 1988 for all industries in our sample. Comparing this ratio with the findings reported in the literature as noted earlier, our estimate is in the middle range. If the upwards bias due to redefinition of activities as $R \& D$ is ignored, it appears that the $R \& D$ tax 
credit has had a modest but significant impact in stimulating R\&D investment. Moreover, if one takes into account the induced output effect from increases of $R \& D$ expenditures, as well as the extent to which there are spillovers from privately-financed R\&D (and the empirical literature supports this hypothesis (see for instance, Nadiri (1991)), and company-financed R\&D and R\&D spillovers are complements, then the benefit-cost ratio of incremental R\&D tax credit will be substantially higher.

Turning now to the evaluation of the relative effectiveness of publiclyfinanced $R \& D$, assume that the social planner's objective is to maximize the producer surpluses generated by publicly-financed $R \& D$. Then the sum of marginal benefit over industries can correspond to a measure of social benefit. ${ }^{14}$ This measure, however, is crude, since the effects of publiclyfinanced $R \& D$ capital on the rest of the economy, as well as the benefits of the particular projects for which has been financed, are not taken into account. Nevertheless, the ratio of benefits to cost of an additional unit of total publicly-financed $R \& D$ is given by

$$
r_{0}-\sum_{h}-\eta_{c_{0}}^{h}\left(c^{h} / G_{0}\right) / q_{G}
$$

where the numerator of $(10)$ is the sum of marginal benefits of Industries from an additional unit of total publicly-financed R\&D capital, and the denominator the marginal cost of an additional unit of publicly-financed R\&D capital taken to be equal to its acquisition price $q_{G}$. Table 9 shows the marginal benefit of total publicly financed $R \& D, G_{0}$. For each additional unit of total publicly-funded $R \& D$, in 1982 industries are willing to pay from $0 \&$ in primary metals (33) to $11 \not$ in electrical equipment(36). The sum of marginal benefits is 78 for each additional unit of publicly-funded R\&D capital, which implies that the rate of return of publicly-funded $R \& D$, calculated using equation (10) 
is about .78 in 1982. This suggests that there might be underinvestment of publicly financed $R \& D$, and that government should increase its investment.

In fact, as Mansfield (1986) has pointed out, some economists have argued that government should abolish the incremental R\&D tax credit because it is Ineffective, and instead increase publicly financed $R \& D$ expenditures by the amount of revenues saved. If this were done, what would be the impact on the industries' production cost and $R \& D$ investment in the manufacturing sector? As noted earlier, the effect of the two instruments on company-financed R\&D are quite different. The publicly-financed $R \& D$ crowds out privately-financed $R \& D$ investment, while the $R \& D$ tax credit induces $1 t$. In table 10 we report the results of the following experiment: First, we assume that for the year 1988 the government abolishes the incremental R\&D tax credit and also that it allows only the economic depreciation of R\&D expenditures to be deducted from the current income. Given our estimates of tables 6 and 7 , these assumptions would imply that the additional cost for the industry or the revenues saved by the government would be about $\$ 16.9$ billion. Second, we assume that the government increases the publicly financed $R \& D$ by the exact amount of revenues saved which represents a 3.67 increase of publicly financed R\&D. Using the total cost elasticities of table 8 , the cost reduction of all industries due to a 3.68 increase of publicly financed $R \& D$ would be $\$ 18.2$ billion. Thus the manufacturing sector would be better off by $\$ 1.3$ billion in terms of potential cost reduction. However, the reduction of R\&D tax incentives would increase the rental price of company-financed R\&D which would reduce R\&D investment by $\$ 16.2$ billion. Onto that amount we have to add an additional $\$ 0.9$ billion of reduction of company-financed $R \& D$ investment due to the crowding out effect of a 3.68 increase of publicly-financed R\&D.

Thus, keeping the government budget constant, an equiproportional change 
of $R \& D$ tax incentives and publicly-financed $R \& D$ would reduce $R \& D$ investment in all industries of the manufacturing sector, and reduce the after-tax cost of the whole sector (see table 10). However, the net effect on cost would not be the same for all industries. Publicly-financed R\&D has a distributive effect: High-tech industries, for instance, machinery (35), electrical equipment (36), and transportation equipment (37), would be worse off, i.e., their after-tax costs would have increased. On the other hand, low-tech industries, for Instance, food and kindred products (20) and other manufacturing industries (42), would be better off. This of course is not surprising since the lowtech industries have very small R\&D cost shares, and thus the removal of the subsidies has relatively smaller effect on their cost.

\section{Conclusion}

We have examined the effects of publicly-funded R\&D and R\&D tax policy on the cost structure of the manufacturing industries at the two-digit level. It has been shown that the effects of publicly-financed R\&D are overall significant and vary across industries. We also found that the publicly financed R\&D performed inside a particular industry has a stronger marginal effect on cost savings compared to that of the publicly financed R\&D performed outside of an industry. Furthermore, the results show that publicly-financed $R \& D$ and company-financed $R \& D$ are substitutes in low $R \& D$ intensive industries, while weak substitutes in high R\&D intensive industries. Thus, an increase in publicly-financed R\&D capital increases the efficiency, in terms of unit cost savings, of the industries of the manufacturing sector, but crowds out privately-financed R\&D investment. On the other hand, our results suggest that the incremental $R \& D$ tax credit is modestly successful in inducing company-financed R\&D. However, if the government had to switch to a regime 
where $R \& D$ expenditures were treated like tangible investment, there would be a substantial reduction in privately-financed $R \& D$ investment. It seems that publicly-financed $R \& D$ investment is a more appropriate tool for increasing efficiency and possibly for stimulating output growth, while the R\&D tax policy is a more appropriate tool for stimulating private sector's R\&D investment. Therefore, both instruments, subsidies and direct financing of publicly financed R\&D expenditures, are important elements for sustaining output growth and productivity increase in the manufacturing sector. 


\section{Appendix}

OUTPUT ( $\mathbf{Y}$ ), LABOR (L), PHYSICAL CAPITAL (K), AND INTERMEDIATE INPUTS (K):

Data on the quantities and price indices of output, labor, physical capital and intermediate inputs were obtained from the Bureau of Labor Statistics (BLS) for the manufacturing industries at the two-digit level, reported in table 1. The sample covers the period from 1956 to 1988. All price indices have been normalized to be equal to one at 1982 value.

For each industry, the quantity of output is measured as the value of gross output divided by the output price index. The value of gross output corresponds to shipments plus the change of inventories, and is inclusive of any portion which is consumed by the same industry. The output price deflator index is implicitly defined by a Tornquist aggregation of four-digit gross outputs.

The labor input quantity is measured as the cost of labor divided by the price of labor index. The labor input is measured in terms of man hours, estimated by the BLS Current Establishment Survey. It corresponds to the sum of hours of all persons engaged in production in the industry. The price deflator of labor is measured implicitly by dividing the labor compensation by the labor hours.

The price of intermediate inputs is derived by a Tornquist index of the price indices of materials, energy, and purchased services, obtained from BLS. The quantity of intermediate inputs is measured as the total cost of materials, energy, and purchased services divided by the price index of intermediate inputs. All price deflators of the above inputs have been constructed implicitly by using a Tornquist index to aggregate the corresponding quantities. ${ }^{15}$

Since own R\&D is explicitly introduced as an input of production, the 
quantities of labor and intermediate inputs are adjusted for their R\&D components in order to avold double counting (see Schankerman (1981)). For labor, the R\&D labor cost, 1.e., the wages of scientists, engineers, and supporting personnel, has been subtracted from the total labor cost; for intermediate inputs, the materials and supplies component of $R \& D$ has been subtracted from the total intermediate input cost. The overhead cost component of R\&D weighted by the cost share of labor and intermediate inputs has been subtracted from both labor and intermediate inputs. The R\&D cost components have been obtained from Research and Development in Industry (various issues). Finally, the prices of output, labor and intermediate inputs are multiplied by one minus the corporate income tax to convert them to after-tax prices. For the period before 1981, the corporate income tax rate has been obtained from Auerbach (1983) and Jorgenson and Sullivan (1981); for the perlod 1981 to 1985 , the rate remains the sane at .46 , while it was reduced to .34 in 1986 by the Tax Reform Act (TRA).

The physical capital stock is defined as the sum of structures and equipment capital stock which have been constructed by the perpetual inventory method. The deflator of physical capital is derived as a Tornquist index of the investment price deflators of structures and equipment.

The rental rate of physical capital is measured as $p_{K}-q_{K}\left(r+\delta_{K}\right)\left(1-{ }^{\imath}{ }_{K}-\right.$ $\left.u_{c} \sigma\right)$ (see Bernstein and Nadiri (1987)), where $q_{k}$ is the physical capital deflator, $r$ is the discount rate taken to be the rate on Treasury notes of ten-year maturity obtained from Citibase, $\delta_{K}$ is the physical capital depreciation rate obtained from BLS, $\iota_{K}$ is the investment tax credit, $u_{c}$ is the corporate income tax rate, and $\sigma$ is the present value of capital consumption allowances. The investment tax credit until 1980 is taken from Jorgenson and Sullivan (1981); 8 is used for 1981, and 7.58 for 1982 to 1985 ; 
finally, the rate is zero for 1986 when it was abolished by the TRA. The present values of capital consumption allowances are constructed as $\sigma-\rho(1-$ $\left.\theta \iota_{K}\right) /(r+\rho)$ (see Bernstein and Nadiri (1987)), where $\rho$ is the capital consumption allowance rate obtained by dividing the capital consumption allowances by the capital stock, and $\theta$ takes value 0 except for the 1962-1963 period in which firms had to reduce the depreciable base of the assets by half of the amount of the investment tax credit under the Long Amendment Act. COMPANY-FINANCED R\&D (R) AND PUBLICLY FINANCED R\&D (G):

Privately-financed $R \& D$ capital is constructed using the perpetual inventory method with a 108 depreciation rate. A constant depreciation rate of 108 has been used in many studies of R\&D spillovers (see, for instance, Bernstein and Nadiri (1990) and U.S. Department of Labor (1989)). An estimate consistent with a 108 depreciation rate for the R\&D capital has also been obtained by Nadiri and Prucha (1994a) in a dynamic production model where the depreciation rate of R\&D capital is endogenously determined. The deflated company-financed R\&D expenditures are accumulated for the period 1956-1988. The initial privately-financed $R \& D$ capital stock is found by dividing the real R\&D expenditures of the year 1957 by the sum of the R\&D depreciation rate and the average growth rate of physical capital for the period 1948-1956. The company-financed $R \& D$ expenditures have been obtained from Research and Development in Industry (various issues). The price deflator of R\&D capital is constructed by linking Mansfield's (1987) constructed deflator series backward with Schankerman's (1979) constructed R\&D deflator series, and forward with the GNP deflator. Mansfield's R\&D deflator series goes from 1969 to 1983. Schankerman's goes from 1957 to 1975. For the years prior to 1957 and after 1983, the Schankerman and Mansfield deflators are linked to the GNP deflator. The after-tax rental rate of $R \& D$ capital is defined by the equation 
(5) In the text (see discussion there and table 4).

The total government R\&D capital stock, $G_{0}$, and the publicly financed R\&D performed within an industry $G_{I}$ are constructed along the same lines as company-financed $R \& D$ capital stock, i.e., by using the perpetual inventory method with a 108 depreciation rate. Data on total federal government financed R\&D expenditures for the period 1970-1988 were obtained from the Federal Funds for Research and Development (1992). For the period 1953-1970, they were obtained from Historical Statistics, Colonial Times to 1970 (1975). These series consist of the total publicly-financed R\&D expenditures performed by the industries, government agents, and nonprofit institutions. The implicit price deflator of government purchases of goods and services. obtained from the Statistical Abstracts of the United States (1990), was used to deflate the R\&D expenditure series. The 1952 benchmark is estimated by dividing the $R \& D$ expenditures by the sum of government $R \& D$ depreciation rate and the growth rate of the government physical capital stock (obtained from the Bureau of Economic Analysis) prior to the sample period. Similarly, for each industry we constructed the internally publicly financed R\&D capital stock $G_{I}$, obtaining data on industry publicly financed $R \& D$ expenditures from Research and Development in Industry (various issues). Then the external publicly financed $R \& D$ capital stock for each industry is defined as $G_{E}-G_{0}$ $G_{I}$. 
Table A.1:Descriptive statistics

(Sample Period: 1956-1988)

\begin{tabular}{|c|c|c|c|c|c|c|c|c|c|c|c|c|c|}
\hline Code & & $\mathrm{TC}$ & $Y$ & SL & sK & SR & SM & $\mathbf{P}_{\mathbf{l}}$ & $\mathbf{P}_{\mathbf{K}}$ & $\mathbf{P}_{\mathbf{R}}$ & $\mathbf{P}_{\mathbf{M}}$ & $G_{1}$ & $G_{z}$ \\
\hline 20 & $\begin{array}{l}\text { Mean } \\
\text { Std. Dev. } \\
\text { Minimum } \\
\text { Maximum }\end{array}$ & $\begin{array}{r}83.92 \\
55.6 \\
26.71 \\
206.4\end{array}$ & $\begin{array}{r}227.50 \\
48.60 \\
153.20 \\
311.80\end{array}$ & 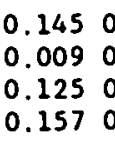 & $\begin{array}{l}0.104 \\
0.025 \\
0.057 \\
0.140\end{array}$ & $\begin{array}{l}0.003 \\
0.001 \\
0.002 \\
0.005\end{array}$ & $\begin{array}{l}0.748 \\
0.030 \\
0.707 \\
0.785\end{array}$ & 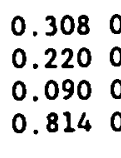 & 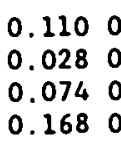 & $\begin{array}{l}0.059 \\
0.042 \\
0.015 \\
0.145\end{array}$ & $\begin{array}{l}0.346 \\
0.181 \\
0.168 \\
0.726\end{array}$ & $\begin{array}{l}0.060 \\
0.026 \\
0.000 \\
0.101\end{array}$ & $\begin{array}{r}289.8 \\
89.2 \\
103.0 \\
375.3\end{array}$ \\
\hline 26 & $\begin{array}{l}\text { Mean } \\
\text { Std. Dev. } \\
\text { Minimum } \\
\text { Maximum }\end{array}$ & $\begin{array}{r}25.9 \\
20.0 \\
6.5 \\
74.0\end{array}$ & $\begin{array}{l}66.10 \\
18.80 \\
36.80 \\
99.40\end{array}$ & 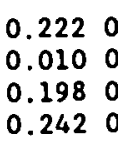 & $\begin{array}{l}0.2190 \\
0.0450 \\
0.124 \mathrm{C} \\
0.294\end{array}$ & $\begin{array}{l}0.006 \\
0.003 \\
0.002 \\
0.011\end{array}$ & $\begin{array}{l}0.553 \\
0.045 \\
0.477 \\
0.638\end{array}$ & $\begin{array}{l}0.3030 \\
0.234 \\
0.084 \\
0.853\end{array}$ & 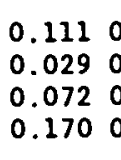 & $\begin{array}{l}0.059 \\
0.042 \\
0.016 \\
0.144\end{array}$ & $\begin{array}{l}0.322 \\
0.197 \\
0.155 \\
0.807\end{array}$ & $\begin{array}{l}0.019 \\
0.016 \\
0.000 \\
0.046\end{array}$ & $\begin{array}{r}289.8 \\
89.1 \\
103.0 \\
375.4\end{array}$ \\
\hline 28 & $\begin{array}{l}\text { Mean } \\
\text { Sed. Dev. } \\
\text { Minimum } \\
\text { Maximum }\end{array}$ & $\begin{array}{r}52.5 \\
43.5 \\
10.3 \\
153.4\end{array}$ & $\begin{array}{r}138.60 \\
49.80 \\
58.60 \\
219.50\end{array}$ & $\begin{array}{l}0.1860 \\
0.0150 \\
0.1520 \\
0.205\end{array}$ & $\begin{array}{l}0.228 \\
0.056 \\
0.116 \\
0.306\end{array}$ & $\begin{array}{l}0.039 \\
0.009 \\
0.024 \\
0.056\end{array}$ & $\begin{array}{l}0.548 \\
0.060 \\
0.463 \\
0.650\end{array}$ & $\begin{array}{l}0.298 \\
0.233 \\
0.082 \\
0.865\end{array}$ & $\begin{array}{l}0.1110 \\
0.030 \\
0.073 \\
0.171\end{array}$ & $\begin{array}{l}0.057 \\
0.043 \\
0.015 \\
0.145\end{array}$ & $\begin{array}{l}0.305 \\
0.193 \\
0.143 \\
0.740\end{array}$ & $\begin{array}{l}4.590 \\
0.879 \\
2.610 \\
5.645\end{array}$ & $\begin{array}{r}285.3 \\
88.6 \\
100.4 \\
371.9\end{array}$ \\
\hline 29 & $\begin{array}{l}\text { Mean } \\
\text { Std. Dev. } \\
\text { Minimum } \\
\text { Maximum }\end{array}$ & $\begin{array}{r}45.0 \\
41.4 \\
8.9 \\
124.7\end{array}$ & $\begin{array}{r}198.20 \\
42.10 \\
126.0 \\
259.7\end{array}$ & $\begin{array}{l}0.0660 \\
0.0170 \\
0.0360 \\
0.091 .0\end{array}$ & $\begin{array}{l}0.162 \\
0.066 \\
0.070 \\
0.258\end{array}$ & $\begin{array}{l}0.015 \\
0.004 \\
0.009 \\
0.025\end{array}$ & $\begin{array}{l}0.756 \\
0.083 \\
0.647 \\
0.884\end{array}$ & $\begin{array}{l}0.286 \\
0.223 \\
0.081 \\
0.786\end{array}$ & $\begin{array}{l}0.100 \\
0.030 \\
0.062 \\
0.160\end{array}$ & $\begin{array}{l}0.058 \\
0.042 \\
0.015 \\
0.144\end{array}$ & $\begin{array}{l}0.196 \\
0.175 \\
0.057 \\
0.541\end{array}$ & $\begin{array}{l}0.704 \\
0.204 \\
0.323 \\
1.035\end{array}$ & $\begin{array}{r}289.1 \\
89.0 \\
102.7 \\
374.6\end{array}$ \\
\hline 30 & $\begin{array}{l}\text { Mean } \\
\text { Std. Dev. } \\
\text { Minimum } \\
\text { Maximum }\end{array}$ & $\begin{array}{r}17.3 \\
14.9 \\
3.2 \\
55.5\end{array}$ & $\begin{array}{l}44.1 \\
19.6 \\
15.8 \\
82.7\end{array}$ & $\begin{array}{l}0.290 \\
0.014 \\
0.261 \\
0.309\end{array}$ & $\begin{array}{l}0.171 \\
0.038 \\
0.085 \\
0.239\end{array}$ & $\begin{array}{l}0.014 \\
0.003 \\
0.008 \\
0.020\end{array}$ & $\begin{array}{l}0.525 \\
0.043 \\
0.449 \\
0.622\end{array}$ & $\begin{array}{l}0.319 \\
0.205 \\
0.115 \\
0.796\end{array}$ & & $\begin{array}{l}0.059 \\
0.043 \\
0.016 \\
0.148\end{array}$ & $\begin{array}{l}0.320 \\
0.192 \\
0.164 \\
0.789\end{array}$ & $\begin{array}{l}1.564 \\
0.384 \\
1.085 \\
2.045\end{array}$ & $\begin{array}{r}288.3 \\
88.9 \\
102.0 \\
373.4\end{array}$ \\
\hline 32 & $\begin{array}{l}\text { Mean } \\
\text { Std. Dev. } \\
\text { Minimum } \\
\text { Maximum }\end{array}$ & $\begin{array}{r}16.6 \\
11.3 \\
4.7 \\
41.8\end{array}$ & $\begin{array}{r}46.9 \\
8.1 \\
31.7 \\
58.9\end{array}$ & $\begin{array}{l}0.290 \\
0.009 \\
0.276 \\
0.309\end{array}$ & $\begin{array}{l}0.235 \\
0.051 \\
0.127 \\
0.308\end{array}$ & $\begin{array}{l}0.011 \\
0.004 \\
0.007 \\
0.019\end{array}$ & & $\begin{array}{l}0.298 \\
0.213 \\
0.087 \\
0.780\end{array}$ & $\begin{array}{l}0.114 \\
0.032 \\
0.073 \\
0.175\end{array}$ & $\begin{array}{l}0.059 \\
0.041 \\
0.017 \\
0.145\end{array}$ & $\begin{array}{l}0.310 \\
0.194 \\
0.136 \\
0.744\end{array}$ & $\begin{array}{l}0.247 \\
0.047 \\
0.168 \\
0.334\end{array}$ & $\begin{array}{r}289.6 \\
89.1 \\
102.8 \\
375.1\end{array}$ \\
\hline 33 & $\begin{array}{l}\text { Mean } \\
\text { Std. Dev. } \\
\text { Minimum } \\
\text { Maximum }\end{array}$ & $\begin{array}{r}47.0 \\
27.3 \\
14.8 \\
103.1\end{array}$ & $\begin{array}{r}130.0 \\
22.1 \\
91.2 \\
174.1\end{array}$ & $\begin{array}{l}0.218 \\
0.008 \\
0.196 \\
0.233\end{array}$ & $\begin{array}{l}0.210 \\
0.034 \\
0.135 \\
0.277\end{array}$ & $\begin{array}{l}0.006 \\
0.002 \\
0.003 \\
0.011\end{array}$ & $\begin{array}{l}0.566 \\
0.036 \\
0.511 \\
0.660\end{array}$ & $\begin{array}{l}0.282 \\
0.202 \\
0.080 \\
0.697\end{array}$ & $\begin{array}{l}0.100 \\
0.030 \\
0.062 \\
0.160\end{array}$ & $\begin{array}{l}0.059 \\
0.043 \\
0.016 \\
0.146\end{array}$ & $\begin{array}{l}0.328 \\
0.187 \\
0.156 \\
0.807\end{array}$ & $\begin{array}{l}0.623 \\
0.665 \\
0.147 \\
2.597\end{array}$ & $\begin{array}{r}289.2 \\
88.9 \\
102.9 \\
372.8\end{array}$ \\
\hline 34 & $\begin{array}{l}\text { Mean } \\
\text { Std. Dev. } \\
\text { Mlnimum } \\
\text { Maximum }\end{array}$ & $\begin{array}{l}38.1 \\
27.1 \\
10.1 \\
99.1\end{array}$ & $\begin{array}{r}114.3 \\
23.0 \\
71.3 \\
144.7\end{array}$ & $\begin{array}{l}0.317 \\
0.011 \\
0.298 \\
0.332\end{array}$ & $\begin{array}{l}0.122 \\
0.017 \\
0.078 \\
0.163\end{array}$ & $\begin{array}{l}0.006 \\
0.002 \\
0.003 \\
0.009\end{array}$ & $\begin{array}{l}0.555 \\
0.021 \\
0.509 \\
0.602\end{array}$ & $\begin{array}{l}0.305 \\
0.213 \\
0.100 \\
0.783\end{array}$ & $\begin{array}{l}0.101 \\
0.028 \\
0.064 \\
0.160\end{array}$ & $\begin{array}{l}0.057 \\
0.043 \\
0.014 \\
0.147\end{array}$ & $\begin{array}{l}0.322 \\
0.197 \\
0.138 \\
0.778\end{array}$ & $\begin{array}{l}0.872 \\
0.288 \\
0.596 \\
1.355\end{array}$ & $\begin{array}{r}289.0 \\
89.4 \\
101.9 \\
374.7\end{array}$ \\
\hline 35 & $\begin{array}{l}\text { Mean } \\
\text { Std. Dev. } \\
\text { Minimum } \\
\text { Maximum }\end{array}$ & $\begin{array}{r}55.3 \\
45.2 \\
11.2 \\
161.6\end{array}$ & $\begin{array}{r}143.2 \\
69.9 \\
56.8 \\
332.1\end{array}$ & $\begin{array}{l}0.333 \\
0.020 \\
0.293 \\
0.359\end{array}$ & $\begin{array}{l}0.133 \\
0.025 \\
0.089 \\
0.176\end{array}$ & $\begin{array}{l}0.032 \\
0.014 \\
0.012 \\
0.060\end{array}$ & $\begin{array}{l}0.502 \\
0.029 \\
0.460 \\
0.550\end{array}$ & $\begin{array}{l}0.306 \\
0.221 \\
0.092 \\
0.819\end{array}$ & $\begin{array}{l}0.103 \\
0.030 \\
0.063 \\
0.161\end{array}$ & $\begin{array}{l}0.059 \\
0.041 \\
0.016 \\
0.143\end{array}$ & $\begin{array}{l}0.317 \\
0.159 \\
0.153 \\
0.621\end{array}$ & $\begin{array}{r}9.326 \\
0.780 \\
7.978 \\
10.503\end{array}$ & $\begin{array}{r}280.5 \\
89.3 \\
95.1 \\
364.9\end{array}$ \\
\hline
\end{tabular}


Table A.1 (cont'd)

\begin{tabular}{|c|c|c|c|c|c|c|c|c|c|c|c|c|c|}
\hline Codt & & TC & $Y$ & SL & SK & SR & SM & $P_{L}$ & $P_{x}$ & $\mathbf{P}_{\mathbf{R}}$ & $P_{H}$ & $C_{1}$ & $C_{E}$ \\
\hline 36 & $\begin{array}{l}\text { Mean } \\
\text { Std. Dev. } \\
\text { Minimum } \\
\text { Maximum }\end{array}$ & $\begin{array}{r}46.71 \\
40.9 \\
8.9 \\
147.52\end{array}$ & $\begin{array}{r}105.00 \\
49.50 \\
36.30 \\
206.7\end{array}$ & $\begin{array}{l}0.334 \\
0.021 \\
0.297 \\
0.367\end{array}$ & $\begin{array}{l}0.114 \\
0.014 \\
0.084 \\
0.148\end{array}$ & $\begin{array}{l}0.049 \\
0.013 \\
0.027 \\
0.070\end{array}$ & $\begin{array}{l}0.503 \\
0.020 \\
0.465 \\
0.541\end{array}$ & $\begin{array}{l}0.310 \\
0.229 \\
0.091 \\
0.860\end{array}$ & $\begin{array}{l}0.108 \\
0.028 \\
0.074 \\
0.166\end{array}$ & $\begin{array}{l}0.059 \\
0.042 \\
0.017 \\
0.146\end{array}$ & $\begin{array}{l}0.344 \\
0.185 \\
0.177 \\
0.787\end{array}$ & $\begin{array}{r}50.227 \\
6.418 \\
35.080 \\
59.439\end{array}$ & $\begin{array}{r}239.6 \\
84.7 \\
68.0 \\
327.0\end{array}$ \\
\hline 37 & $\begin{array}{l}\text { Mean } \\
\text { Std. Dev. } \\
\text { Minimum } \\
\text { Maxinum }\end{array}$ & $\begin{array}{r}79.72 \\
62.6 \\
19.81 \\
237.5\end{array}$ & $\begin{array}{r}214.4 \\
55.4 \\
116.3 \\
328.2\end{array}$ & $\begin{array}{l}0.248 \\
0.009 \\
0.234 \\
0.265\end{array}$ & $\begin{array}{l}0.120 \\
0.026 \\
0.063 \\
0.178\end{array}$ & $\begin{array}{l}0.035 \\
0.014 \\
0.014 \\
0.062\end{array}$ & $\begin{array}{l}0.597 \\
0.025 \\
0.533 \\
0.641\end{array}$ & $\begin{array}{l}0.309 \\
0.230 \\
0.082 \\
0.827\end{array}$ & $\begin{array}{l}0.115 \\
0.030 \\
0.076 \\
0.174\end{array}$ & $\begin{array}{l}0.058 \\
0.042 \\
0.016 \\
0.145\end{array}$ & $\begin{array}{l}0.323 \\
0.194 \\
0.151 \\
0.769\end{array}$ & $\begin{array}{r}108.644 \\
15.908 \\
72.300 \\
129.930\end{array}$ & $\begin{array}{r}181.6 \\
77.2 \\
30.8 \\
248.3\end{array}$ \\
\hline 38 & $\begin{array}{l}\text { Mean } \\
\text { Std. Dev, } \\
\text { Minimum } \\
\text { Maximum }\end{array}$ & $\begin{array}{r}13.4 \\
12.4 \\
2.3 \\
44.2\end{array}$ & $\begin{array}{l}34.4 \\
16.6 \\
14.0 \\
66.4\end{array}$ & $\begin{array}{l}0.375 \\
0.030 \\
0.328 \\
0.420\end{array}$ & $\begin{array}{l}0.127 \\
0.023 \\
0.076 \\
0.177\end{array}$ & $\begin{array}{l}0.053 \\
0.025 \\
0.021 \\
0.097\end{array}$ & $\begin{array}{l}0.446 \\
0.027 \\
0.398 \\
0.494\end{array}$ & $\begin{array}{l}0.310 \\
0.227 \\
0.095 \\
0.853\end{array}$ & $\begin{array}{l}0.113 \\
0.029 \\
0.079 \\
0.171\end{array}$ & $\begin{array}{l}0.058 \\
0.042 \\
0.016 \\
0.144\end{array}$ & $\begin{array}{l}0.345 \\
0.186 \\
0.148 \\
0.785\end{array}$ & $\begin{array}{l}4.243 \\
0.415 \\
3.197 \\
4.816\end{array}$ & $\begin{array}{r}285.6 \\
88.8 \\
99.9 \\
371.3\end{array}$ \\
\hline 40 & $\begin{array}{l}\text { Mean } \\
\text { Std. Dev. } \\
\text { Minimum } \\
\text { Maximum }\end{array}$ & $\begin{array}{r}39.5 \\
30.4 \\
11.1 \\
117.8\end{array}$ & $\begin{array}{r}119.1 \\
23.0 \\
79.7 \\
162.0\end{array}$ & $\begin{array}{l}0.340 \\
0.010 \\
0.320 \\
0.359\end{array}$ & $\begin{array}{l}0.117 \\
0.019 \\
0.070 \\
0.156\end{array}$ & $\begin{array}{l}0.003 \\
0.002 \\
0.001 \\
0.006\end{array}$ & $\begin{array}{l}0.539 \\
0.023 \\
0.489 \\
0.585\end{array}$ & $\begin{array}{l}0.324 \\
0.220 \\
0.107 \\
0.850\end{array}$ & $\begin{array}{l}0.114 \\
0.028 \\
0.079 \\
0.171\end{array}$ & $\begin{array}{l}0.057 \\
0.043 \\
0.014 \\
0.145\end{array}$ & $\begin{array}{l}0.335 \\
0.198 \\
0.155 \\
0.809\end{array}$ & $\begin{array}{l}1.006 \\
0.667 \\
0.228 \\
2.192\end{array}$ & $\begin{array}{r}288.8 \\
89.8 \\
101.3 \\
375.1\end{array}$ \\
\hline 41 & $\begin{array}{l}\text { Mean } \\
\text { Std. Dev. } \\
\text { Minimum } \\
\text { Maximum }\end{array}$ & $\begin{array}{l}34.8 \\
20.3 \\
12.9 \\
81.0\end{array}$ & $\begin{array}{r}87.8 \\
20.7 \\
53.0 \\
120.5\end{array}$ & $\begin{array}{l}0.281 \\
0.007 \\
0.266 \\
0.295\end{array}$ & $\begin{array}{l}0.109 \\
0.022 \\
0.060 \\
0.143\end{array}$ & $\begin{array}{l}0.002 \\
0.001 \\
0.000 \\
0.003\end{array}$ & $\begin{array}{l}0.608 \\
0.021 \\
0.565 \\
0.657\end{array}$ & $\begin{array}{l}0.320 \\
0.215 \\
0.109 \\
0.824\end{array}$ & $\begin{array}{l}0.118 \\
0.028 \\
0.083 \\
0.176\end{array}$ & $\begin{array}{l}0.057 \\
0.043 \\
0.014 \\
0.145\end{array}$ & $\begin{array}{l}0.370 \\
0.155 \\
0.236 \\
0.729\end{array}$ & $\begin{array}{l}0.062 \\
0.032 \\
0.029 \\
0.123\end{array}$ & $\begin{array}{r}289.8 \\
89.2 \\
103.0 \\
375.3\end{array}$ \\
\hline 42 & $\begin{array}{l}\text { Mean. } \\
\text { Std. Dey. } \\
\text { Minimum } \\
\text { Maximum }\end{array}$ & $\begin{array}{r}24.7 \\
19.0 \\
6.6 \\
71.5\end{array}$ & $\begin{array}{l}61.0 \\
16.4 \\
37.2 \\
94.7\end{array}$ & $\begin{array}{l}0.299 \\
0.016 \\
0.274 \\
0.328\end{array}$ & $\begin{array}{l}0.135 \\
0.033 \\
0.064 \\
0.178\end{array}$ & $\begin{array}{l}0.002 \\
0.001 \\
0.001 \\
0.004\end{array}$ & $\begin{array}{l}0.564 \\
0.042 \\
0.505 \\
0.639\end{array}$ & $\begin{array}{l}0.315 \\
0.221 \\
0.096 \\
0.823\end{array}$ & $\begin{array}{l}0.122 \\
0.030 \\
0.085 \\
0.182\end{array}$ & $\begin{array}{l}0.057 \\
0.043 \\
0.014 \\
0.145\end{array}$ & $\begin{array}{l}0.342 \\
0.206 \\
0.140 \\
0.791\end{array}$ & $\begin{array}{l}0.007 \\
0.005 \\
0.000 \\
0.015\end{array}$ & $\begin{array}{r}289.8 \\
89.2 \\
103.0 \\
375.4\end{array}$ \\
\hline
\end{tabular}


1 The authors would like to thank Bhaswar Mukhopadhyay and Richard Simon for their help in preparing this manuscript and two referees for very constructive and helpful comments. We also acknowledge support from the C.V. Starr Center for Applied Economics of New York University.

2 See, for instance, Arrow (1969), Atkinson and Stiglitz (1980), and Varian (1984).

3 Evidence of the effectiveness of $R \& D$ tax incentives in encouraging privately-financed $R \& D$ spending is somewhat mixed. Evidence from tax returns (Cordes (1989, 1988)), from surveys (Mansfield (1985, 1986)), from comparisons of the user cost (Cordes (1984), Cordes et al. (1987), Fullerton and Lyon (1983), and Hulten and Robertson (1984)), and from econometric estimates (Baily et al. (1985), Baily and Lawrence (1992), Hines (1991), and Hall (1992)) are not unambiguous. See Cordes (1988, 1989) for a review.

- Studies conducted at the industry or firm level, which usually estimate total factor productivity regressions (see Leonard (1971). Terleckyj (1974, 1984), Griliches (1980, 1986), Griliches and Lichtenberg (1984) and Lichtenberg and siegel (1989)), have not found any evidence of a significant productivity effect from government funded R\&D. Bartelsman (1990) has provided a mixture of evidence, while Nadiri and Mamuneas (1994) and Mamuneas (1993)), in a cost function framework, have found significant effects of total publicly-funded R\&D. For a collection of case studies dealing with the effects of federal government's R\&D policy see Nelson (1982).

${ }^{3}$ Half of the industries in our sample, especially the low tech industries, perform trivial or zero amounts of publicly-financed R\&D. Since the logarithm of zero is not defined, for the purpose of estimation we redefined the logarithm of internally performed public R\&D as $\ln z-\ln \left(1+G_{1}\right)$. This transformation does not affect the parameter estimates but should be taken into account when elasticities are calculated.

- We have imposed constant returns to scale on conventional inputs--1abor, capital, and intermediate inputs--while the privately financed R\&D capital is allowed to capture the degree of internal returns to scale in the industry. This was a necessary restriction, since preliminary estimation of a more general cost function caused the returns to scale to be unreasonably high and unstable. The technological change parameters consistently had the wrong sign, making it difficult to distinguish shifts of the cost function due to scale or technological change over time. Also note that we initially experimented with a more flexible functional form of cost function. These attempts were also not fruitful since the second order conditions were always violated.

The credit has from then renewed at a rate of 208. See Hall (1992) for a brief history of the credit rate, qualified expenditure rules and base levels during the period 1981-91. 
- The parameter $\lambda$ can be considered as the rate with which R\&D expenditures are allowed to be deducted in the current period. To see the significance of immediate expensing of $R \& D$ expenditures compare it with the case in which the government allows only the economic depreciation of R\&D expenditures to be deducted from current income. The present value of the depreciation deductions of $\$ 1$ of R\&D with a depreciation and discount rate of 108 is equal to $.50(-.10 /(.10+.10))$ and the parameter $\lambda$ takes the value .50 .

9 For $1981 \nu-\left(1-.5 /(1+r)-\sum_{1=2}^{3} .33 /(1+r)^{1}\right)$ since for 1982 the base was the average of R\&D expenditures of 1980 and 1981 (see Eisner et al. (1984)).

10 However, the hypothesis that the mean elasticities are equal across industries has been tested and rejected.

11 The elasticity of cost with respect of Tax incentives is given by

$$
\eta_{\mathrm{C} T}^{\mathrm{h}}=\partial \ln \mathrm{C}^{\mathrm{h}} / \partial \ln \mathrm{T}=\mathrm{S}_{\mathrm{R}}^{\mathrm{h}}\left(\partial \ln \mathrm{p}_{\mathrm{R}}^{\mathrm{h}} / \partial \ln \mathrm{T}\right)
$$

12 Cordes (1989) has estimated that the credit stimulated about $\$ 560$

million to $\$ 1.5$ billion, while Hall (1992) has estimated that the additional spending stimulated is about $\$ 2$ billion 1982 dollars per year.

13 Note that by construction $G_{I}^{h}-\pi_{I}^{h} G_{0}$ and $G_{E}^{h}-\left(1-\pi_{I}^{h}\right) G_{0}$, where $\pi_{I}^{h}$ is the ratio of internally publicly-financed $R \& D$ to total publicly-financed R\&D in industry $h$.

14 Kaizuka (1965) was the first to derive the conditions of production efficiency when collective goods are used as inputs in the production process. Sandmo (1972) explored the general equilibrium implications of these conditions.

15 For a detailed description and construction of data obtained from BLS, see Gullickson and Harper $(1986,1987)$. 


\section{References}

Arrow, K. J., 1969, The Organization of Economic Activity: Issues Pertinent to the Cholce of Market versus Non-Market Allocation, in The Analysis and Evaluation of Public Expenditures: The PPB System, 47-64, Joint

- Economic Committee of the Congress of the United States, Washington, D.C.

1962, Economic Welfare and the Allocations of Resources for Invention, in $R$. Nelson, ed. The Rate and Direction of Inventive Activity: Economic and Social Factors, NBER, Princeton University Press, Princeton.

Atkinson, B. A. and J. E. Stiglitz, 1980, Lectures on Public Economics, McGraw-Hill Book Company, New York.

Auerbach, J. A., 1983, Corporate Taxation in the United States, Brookings Papers and Economic Activity, 2, 451-513.

Baily, M. N. and R. Z. Lawrence, 1992, Tax Incentives for R\&D: What Do the Data Tell Us?, study commissioned by the Council on Research and Technology, Washington, D.C.

Baily, M. N., R. Z. Lawrence and Data Resources Inc., 1985, The Need for a Permanent Tax Credit for Industrial Research and Development, Report to the Coalition for the Advancement, of Industrial Technology.

Bartelsman, E. J., 1990, R\&D Spending and manufacturing Productivity: An Empirical Analysis, Working paper, Division of Research and statistics, Board of Governors of the Federal Reserve System, January.

Bernstein, J., 1986, Research and Development, Tax Incentives and the structure of Production and Financing. University of Toronto Press, Toronto.

Bernstein J. and M. I. Nadiri, 1990, Product Demand, Cost of Production, Spillovers, and the Social Rate of Return to R\&D, NBER Working Paper 3625, February.

1989, Rates of Return on Physical and R\&D Capital and Structure of Production Process: Cross Section and Time Series Evidence, in Baldev Raj, ed., Advances in Econometrics and Modeling, Kluwer, Dordrecht, the Netherlands.

- 1987. Corporate Taxes and Incentives and the Structure of Producticn: A Selective Survey, in J. Mintz and D. Purvis, eds., The Impact of Taxation on Business Activity. J. Deutsch Institute for the Studies of Economic Policy, Kingston Ontario.

Carmichael, J., 1981, The Effects of Mission-Oriented Public R\&D Spending on Private Industry, Journal of Finance 36, 617-27. 
Cohen, W. M. and R. C. Levin, 1989. Empirical Studies of Innovation and Market Structure," in R. Scmalenses and R. D. Willing, eds., Handbook of Industrial Organization, vol. II, North Holland, New York.

Cordes, J. J., 1989, Tax Incentives and R\&D Spending: A Review of the Evidence, Research Policy 18, 119-133.

- 1988, The Impact of Tax Policy on the Creation of New Technical Knowledge: An Assessment of the Evidence, in Cyert, $R$. and D. Mawrey, eds. The Effect of Technological Change on Employment and Economic Growth, Bullinger Publishing Co., Cambridge, MA.

, 1984, R\&D Tax Incentives, in Brown, K., ed., The R\&D Tax Credit: Issues in Tax policy and Industrial Innovations, American Enterprise Institute for Public Policy, Washington D.C.

Cordes, J. J., Watson S. H. and J. S. Hauger, 1987, Effects of Tax Reform on High Technology Firms, National Tax Journal, 40 (3), 373-391.

Diewert, E. W., 1986, The Measurement of the Economic Benefits of Infrastructure Services, Lecture Notes in Economic and Mathematical Systems, Spinger-Verlag.

, 1974, Applications of Duality Theory, in M. D. Intrilligator and D. A. Kendrick, ed., Frontiers of Quantitative Economics, Vol. II, NorthHolland Publishing Company.

Eisner, R., S. Albert, and M. A. Sullivan, 1984, The New Incremental Tax Cxedit for R\&D: Incentive ox Disincentive?. National Tax Journal, June, $171-83$.

Fullerton, D. and A. B. Lyon, 1983, Differential Effects of the Accelerated Cost Recovery System on Investment: A Survey, with Implications for Understanding Effects on High Technology Investment, NSF/PRA-83040, October.

Goldberg, L., 1979, The Influence of Federal R\&D Funding on the Demand for and Returns to Industrial R\&D, Public Research Institute, Center for Naval Analysis, Crc $388 /$ October, Alexandria, VA.

Griliches, Z., 1991, The Search for R\&D Spillovers, Scandinavian Journal of Economics, Supplement, 94, 29-47.

- 1986, Productivity, R\&D and Basic Research at the Firm Level in the $1970^{\prime} s$, American Economic Review 76 (1), 141-154.

- 1980, R\&D and Productivity Slowdown, American Economic Review 70 (2), $343-348$.

1979, Issues in Assessing the Contribution of Research and Development to Productivity Growth, Bell Journal of Economics 10 (1), 92-116.

Griliches, Z. and F. Lichtenberg, 1984, Interindustry Technology Flows and 
Productivity Growth: a Reexamination, Review of Economics and statistics 66 (2), 324-29.

Gullickson, W. and M. J. Harper, 1987, Multifactor Productivity in U.S. Manufacturing, 1949-83, Monthly Labor Review 110 (10), 18-28.

1986. Multifactor Productivity Measurement for Two-Digit Manufacturing Industries, Paper Presented at the Meeting of the Western Economic Association, July, San Francisco.

Hall, B. H., 1992, R\&D Tax Policy During the Eighties: Success or Failure?, paper prepared for the NBER Tax Policy Conference, Washington, D.C.

Hall, R. E. and D. Jorgenson, 1967, Tax Policy and Investment Behavior, American Economic Review 57, 391-414.

Hines, J. R., 1991, On the Sensitivity of R\&D to Delicate Tax Changes: The Behavior of US Multinationals in the 1980s, mimeo.

Hulten, C. R. and J. W. Robertson, 1984, The Taxation of High Technology Industries, National Tax Journal 37, 334-345.

Jaffe, A. B., 1989, Real Effects of Academic Research, American Economic Review 79 (5), 957-970.

Jorgenson, D., 1986, Econometric Methods for Modeling Producer Behavior, in Z. Griliches and M. D. Intriligator, ed., Handbook of Econometrics, Vol. III, Ch. 31, Elsevier Science Publishers, BV.

Jorgenson, D. and M. A. Sullivan, 1981, Inflation and Corporate Capital Recovery, in C. R. Hulten, ed., Depreciation, Inflation and the Taxation of Income from Capital, Urban Institute, Washington.

Kaizuka, K., 1965, Public Goods and Decentralization of Production, Review of Economics and statistics 47, 118-20.

Leonard, W. N., 1971, Research and Development in Industrial Growth, Journal of Political Economy 79 (2).

Levin, R. and P. Reiss, 1984, Tests of a Schumpeterian Model of R\&D and Market Structure, in Z. Griliches, ed., R\&D, Patents, and Productivity, NBER, The University of Chicago Press, Chicago.

Levy, D. M. and N. E. Terleckyj, 1983, Effects of Government R\&D on Private R\&D Investment and Productivity: A Macroeconomics Analysis, The Bell Journal of Economics 14 (2).

Lichtenberg, F. R., 1988, The Private R\&D Investment Response to Federal Design and Technical Competitions, American Economic Review 78, 550 559 .

- 1984, The Relationship Between Federal Contract R\&D and Company R\&D, American Economic Review, May, 73-78. 
Lichtenberg, F. R. and Slegel, 1989, The Input of R\&D Investment on Productivity: New Evidence Using Linked R\&D-LRD Data, NBER Working Paper No. 2901, March.

Link, A. N., 1982, An Analysis of the Composition of R\&D Spending, Southern Economic Journal, October.

Mamuneas, Th. P., 1993, Spillovers from Publicly Financed R\&D Capital in HighTech Industries, mimeo.

Mansfield, E., 1994, Comments, Brookings Papers on Economic Activity, forthcoming.

1987, Price Indexes for R\&D Inputs, 1969-1983, Management Science, (1) January, 124-129.

1986, The R\&D Tax Credit and Other Technology Pollcy Issues, American Economic Review 76(2), 190-194.

1985, Public Policy Toward Industrial Innovation: An International Study of Direct Tax Incentives for R\&D, in R. Hayes, $K$. Clark, and $C$. Lorenz, eds., The Uneasy Alliance: Managing the ProductivityTechnology Dilemma, Harvard Business Scool, Boston, 383-407.

Mohnen, P., 1990, Relationship between R\&D and Productivity Growth in Canada and other Major Industrialized Countries, Report for the Economic Council of Canada.

- 1989, New Technologies and Inter-Industries Sp1llovers, CERPE, Working Paper No. 8, University of Montreal.

Nadiri, M. I., 1993, Innovations and Technological Spillovers, NBER Working Paper 4423.

- 1980, Contributions and Determinants of R\&D Expenditures in the U. S. Manufacturing Industry, in G. M. Furstenberg, ed., Capital Efficiency and Growth, Ballinger Publishing Company, Cambridge.

Nadir1, M. I. and Th. P. Mamuneas, 1994. The Effects of Public Infrastructure and R\&D Capital on the Cost Structure and Performance of U.S. Manufacturing Industries, Review of Economics and statistics, 76 (1), $22-37$

Nadiri, M. I. and I. R. Prucha, 1994a, Estimation of the Depreciation Rate of Physical and R\&D Capital in the U.S. Manufacturing Sector, Economic Inquiry, forthcoming.

- 1994b, Dynamic Factor Demand Models, Productivity Measurement, and Rates of Return: Theory and An Empirical Application to the U.S. Bell System, Journal of Econometrics, forthcoming.

National Science Foundation (various issues), Research and Development in 
Industry, Survey of Science Resources Series, Washington, D.C.

1992, Federal Funds for Research and Development. Detailed Historical Tables: Fiscal Years 1956-1992, Division of Science Resources Studies, Washington, D.C.

Nelson, R. R., 1982, Government and Technical Progress: A Cross-Industry Analysis, Pergamon Press, New York.

Romer, P., 1990, Are Nonconvexities Important for Understanding Growth, American Economic Review 80 (2), 97-103.

Sandmo, A., 1972, Optimality Rules for the Provision of Collective Factors of Production, Journal of Public Economics 1, 149-57.

Schankerman, M., 1981, The Effects of Double-Counting and Expensing on the Measured Returns to R\&D, Review of Economics and statistics 63 (3), 454-58.

- 1979. The Determinants, Rates of Return and Productivity Impact of Research and Development, Unpublished Ph.D. Dissertation, Harvard University.

Schankerman, M. and M. I. Nadiri, 1986, A Test of Static Equilibrium Models and Rates of Return to Quasi-Fixed Factors, with an Application to the Bell System, Journal of Econometrics 33, 97-118.

Scott, J. T., 1984, Firm Versus Industry Variability in R\&D Intensity, in 2. Griliches, R\&D, Patents, and Productivity, NBER. The University of Chicago Press, Chicago.

Spence, M., 1984, Cost-Reduction, Competition and Industry Performance, Econometrica 52 (1), 101-21.

Terleckyj, N., 1984, Economic Effects of Government R\&D Spending in the United States, Final Report to the NSF, Washington, D.C.

1974, Effects of R\&D on the Productivity Growth of Industries: An Exploratory study. National Planning Association, Washington, D.C.

U. S. Congress, 1984, Federal support for R\&D and Innovation, Congressional Budget office, April.

U. S. Department of Commerce (various issues), statistical Abstract of the United states, Washington, D.C.

U. S. Department of Commerce, 1975, Historical statistics of the United states, Colonial Times to 1970, Washington, D.C.

U. S. Department of Labor, 1989, The Impact of Research and Development on Productivity Growth, Bulletin 2331.

Varian, H. R., 1984, Microeconomic Analysis, W. W. Norton \& Company, New York. 
Table 1: sIc classification

\begin{tabular}{lll} 
Code & SIC Codes & Industry \\
20 & 20 & Food and Kindred Products \\
26 & 26 & Paper and Allied Products \\
28 & 28 & Chemicals and Allied Products \\
29 & 29 & Petroleum Refining and Related Industries \\
30 & 30 & Rubber Products \\
32 & 32 & Stone, Clay, and Glass Products \\
33 & 33 & Primary Metals \\
34 & 34 & Fabricated Metal Products \\
35 & 35 & Machinery \\
36 & 36 & Electrical Equipment \\
37 & 37 & Transportation Equipment \\
38 & 38 & Scientific Instruments \\
40 & 22,23 & Textiles and Apparel \\
41 & 24,25 & Lumber, Wood Products, and Furniture \\
42 & $21,27,31,39$ & other Manufacturing Industries \\
\hline
\end{tabular}


Table 2: Estimation Results*

(Sample Period:1956-1988; Number of Industries:15)

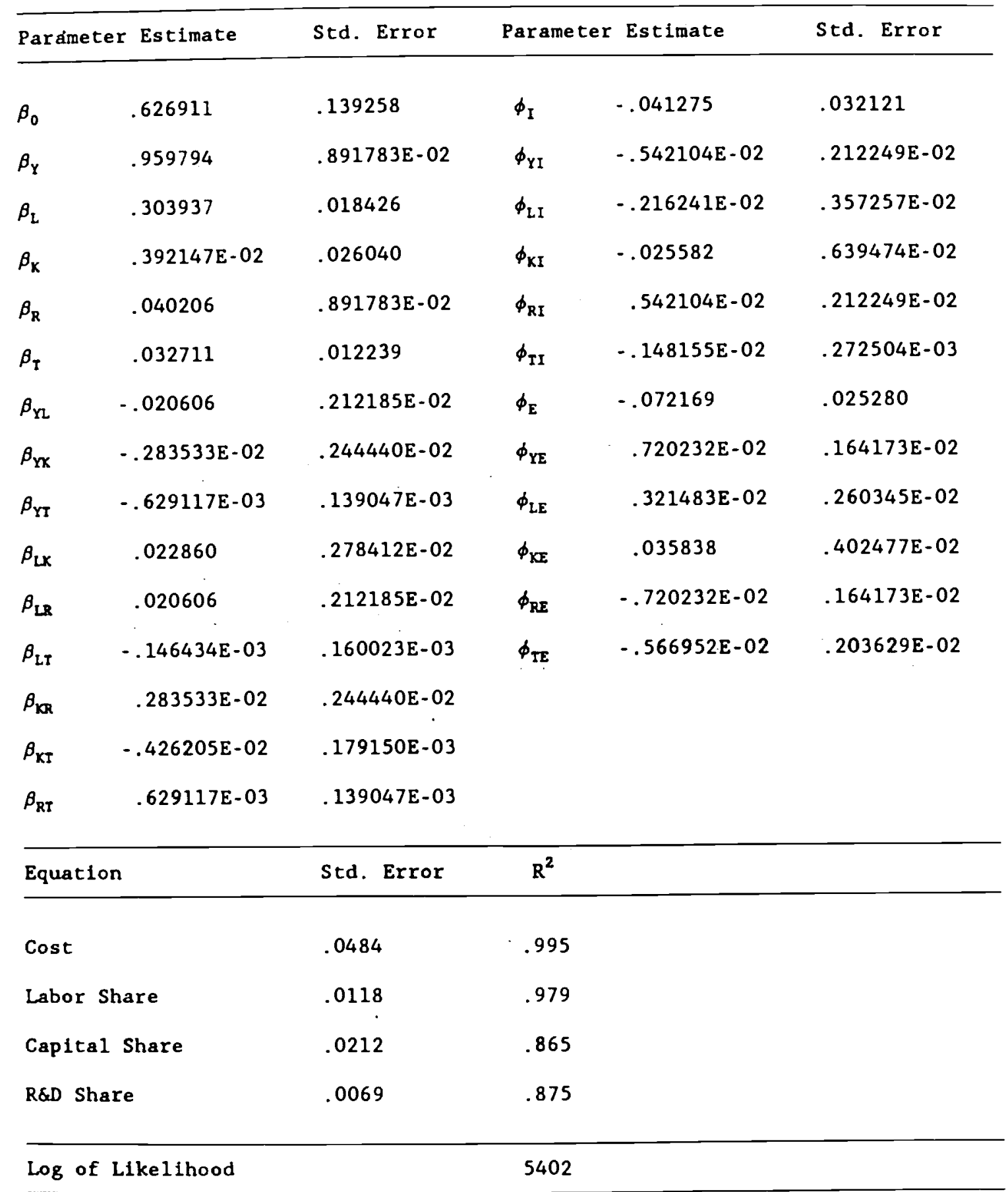

- Dumny Parameters are not reported. 


$$
-37 \text {. }
$$

Table 3: Bypothesis Testing

\begin{tabular}{|c|c|c|c|}
\hline Specification & g of Likel. & $x^{2} /$ d.fr. & $x_{c, 0.0 s / d . f r}^{2}$ \\
\hline 1. $\quad \alpha_{0}-\alpha_{L}-\alpha_{K}-\alpha_{R}-\gamma_{L}-0$ & 3314 & 59.65 & 1.29 \\
\hline 2. $\quad \alpha_{0}-\alpha_{\mathrm{L}}-\alpha_{\mathrm{K}}-\alpha_{\mathrm{R}}-0$ & 3552 & 66.07 & 1.33 \\
\hline 3. $\gamma_{\mathrm{a}}-\phi_{\mathrm{a}}=0$ & 5207 & 16.25 & 1.52 \\
\hline 4. $\phi_{I}=0$ & 5377 & 26.00 & 2.21 \\
\hline 5. $\phi_{E}=0$ & 5346 & 22.40 & 2.21 \\
\hline 6. $\beta_{\mathrm{t}}-\beta_{\mathrm{LI}}-\beta_{\mathrm{KI}}-\beta_{\mathrm{RI}}-\phi_{\mathrm{I} I}=0$ & 5170 & 77.330 & 2.01 \\
\hline
\end{tabular}


Table 4: Unit Cost of Companj Flnanced B\&D Investment

\begin{tabular}{|c|c|c|c|c|c|}
\hline Period & $\begin{array}{l}\text { After Tax } \\
\text { Cost }\end{array}$ & Expensing & $\begin{array}{c}\text { Effective } \\
\text { R\&D Tax } \\
\text { Credit }\end{array}$ & $\begin{array}{l}\text { Statutory } \\
\text { R\&D Tax } \\
\text { Credit }\end{array}$ & $\begin{array}{l}\text { Discount } \\
\text { Rate }\end{array}$ \\
\hline & & $\lambda u_{c}$ & 25 & 5 & $r$ \\
\hline 1981 & 0.520 & 0.46 & 0.020 & 0.25 & 0.140 \\
\hline 1982 & 0.487 & 0.46 & 0.053 & 0.25 & 0.130 \\
\hline 1983 & 0.493 & 0.46 & 0.047 & 0.25 & 0.110 \\
\hline 1984 & 0.489 & 0.46 & 0.051 & 0.25 & 0.120 \\
\hline 1985 & 0.495 & 0.46 & 0.045 & 0.25 & 0.110 \\
\hline 1986 & 0.633 & 0.34 & 0.027 & 0.20 & 0.077 \\
\hline 1987 & 0.631 & 0.34 & 0.029 & 0.20 & 0.084 \\
\hline 1988 & 0.629 & 0.34 & 0.031 & 0.20 & 0.089 \\
\hline Average & 0.547 & 0.42 & 0.038 & 0.23 & 0.107 \\
\hline
\end{tabular}


Table 5:Conditional Input Demand Price Elasticities

(1982 Values; Stand. Error in Parenthesis)

\begin{tabular}{|c|c|c|c|c|c|}
\hline Code & Demand & Labor & $\begin{array}{r}\text { Phys Ical } \\
\text { Capital }\end{array}$ & $\begin{array}{c}R \& D \\
\text { Capital }\end{array}$ & $\begin{array}{l}\text { Interm. } \\
\text { Inputs }\end{array}$ \\
\hline \multirow[t]{4}{*}{20} & Labor & $\begin{array}{l}-0.8575 \\
(0.0124)\end{array}$ & $\begin{array}{c}0.2370 \\
(0.0325)\end{array}$ & $\begin{array}{c}0.1566 \\
(0.0039)\end{array}$ & $\begin{array}{c}0.4639 \\
(0.0218)\end{array}$ \\
\hline & Phys. Capital & $\begin{array}{c}0.4410 \\
(0.0783)\end{array}$ & $\begin{array}{l}-0.9234 \\
(0.0146)\end{array}$ & $\begin{array}{c}0.0490 \\
(0.0255)\end{array}$ & $\begin{array}{c}0.4335 \\
(0.0459)\end{array}$ \\
\hline & R\&D Capital & $\begin{array}{c}1.8689 \\
(0.2795)\end{array}$ & $\begin{array}{c}0.3141 \\
(0.2132)\end{array}$ & $\begin{array}{l}-0.9881 \\
(0.0013)\end{array}$ & $\begin{array}{l}-1.1949 \\
(0.2511)\end{array}$ \\
\hline & Inter. Inputs & $\begin{array}{c}0.0859 \\
(0.0107)\end{array}$ & $\begin{array}{c}0.0432 \\
(0.0124)\end{array}$ & $\begin{array}{l}-0.0185 \\
(0.0032)\end{array}$ & $\begin{array}{l}-0.1106 \\
(0.0106)\end{array}$ \\
\hline \multirow[t]{4}{*}{26} & Labor & $\begin{array}{l}-0.7860 \\
(0.0096)\end{array}$ & $\begin{array}{c}0.2967 \\
(0.0191)\end{array}$ & $\begin{array}{c}0.1103 \\
(0.0059)\end{array}$ & $\begin{array}{c}0.3790 \\
(0.0123)\end{array}$ \\
\hline & Phys. Capital & $\begin{array}{c}0.3344 \\
(0.0203)\end{array}$ & $\begin{array}{l}-0.8101 \\
(0.0115)\end{array}$ & $\begin{array}{c}0.0289 \\
(0.0123)\end{array}$ & $\begin{array}{c}0.4469 \\
(0.0149)\end{array}$ \\
\hline & R\&D Capital & $\begin{array}{c}1.6901 \\
(0.2164)\end{array}$ & $\begin{array}{c}0.3930 \\
(0.1842)\end{array}$ & $\begin{array}{l}-0.9860 \\
(0.0013)\end{array}$ & $\begin{array}{l}-1.0970 \\
(0.2100)\end{array}$ \\
\hline & Inter. Inputs & $\begin{array}{c}0.1393 \\
(0.0081)\end{array}$ & $\begin{array}{c}0.1458 \\
(0.0092)\end{array}$ & $\begin{array}{l}-0.0263 \\
(0.0043)\end{array}$ & $\begin{array}{l}-0.2588 \\
(0.0095)\end{array}$ \\
\hline \multirow[t]{4}{*}{28} & Labor & $\begin{array}{l}-0.8236 \\
(0.0111)\end{array}$ & $\begin{array}{c}0.3234 \\
(0.0244)\end{array}$ & $\begin{array}{c}0.1620 \\
(0.0052)\end{array}$ & $\begin{array}{c}0.3382 \\
(0.0151)\end{array}$ \\
\hline & Phys. Capital & $\begin{array}{c}0.2944 \\
(0.0214)\end{array}$ & $\begin{array}{l}-0.8062 \\
(0.0132)\end{array}$ & $\begin{array}{c}0.0598 \\
(0.0118)\end{array}$ & $\begin{array}{c}0.4520 \\
(0.0145)\end{array}$ \\
\hline & R\&D Capital & $\begin{array}{c}0.6324 \\
(0.0603)\end{array}$ & $\begin{array}{c}0.2566 \\
(0.0667)\end{array}$ & $\begin{array}{l}-0.9548 \\
(0.0013)\end{array}$ & $\begin{array}{c}0.0658 \\
(0.0595)\end{array}$ \\
\hline & Inter. Inputs & $\begin{array}{c}0.1021 \\
(0.0094)\end{array}$ & $\begin{array}{c}0.1499 \\
(0.0106)\end{array}$ & $\begin{array}{c}0.0051 \\
(0.0045)\end{array}$ & $\begin{array}{l}-0.2570 \\
(0.0102)\end{array}$ \\
\hline \multirow[t]{4}{*}{29} & Labor & $\begin{array}{l}-0.9664 \\
(0.0112)\end{array}$ & $\begin{array}{c}0.7851 \\
(0.2746)\end{array}$ & $\begin{array}{c}0.6218 \\
(0.1444)\end{array}$ & $\begin{array}{l}-0.4405 \\
(0.4057)\end{array}$ \\
\hline & Phys. Capital & $\begin{array}{c}0.2533 \\
.(0.0458)\end{array}$ & $\begin{array}{l}-0.8959 \\
(0.0130)\end{array}$ & $\begin{array}{c}0.0351 \\
(0.0197)\end{array}$ & $\begin{array}{c}0.6076 \\
(0.0255)\end{array}$ \\
\hline & R\&D Capital & $\begin{array}{c}2.6581 \\
(0.7419)\end{array}$ & $\begin{array}{c}0.4652 \\
(0.3616)\end{array}$ & $\begin{array}{l}-0.9921 \\
(0.0018)\end{array}$ & $\begin{array}{l}-2.1311 \\
(0.9104)\end{array}$ \\
\hline & Inter. Inputs & $\begin{array}{l}-0.0173 \\
(0.0102)\end{array}$ & $\begin{array}{r}0.07401 \\
(0.0116)\end{array}$ & $\begin{array}{r}-0.01961 \\
(0.0043)\end{array}$ & $\begin{array}{r}-0.03711 \\
(0.0116)\end{array}$ \\
\hline
\end{tabular}


Table 5 (cont'd)

\begin{tabular}{|c|c|c|c|c|c|}
\hline $\begin{array}{c}\text { Code } \\
.\end{array}$ & Demand & Labor & $\begin{array}{r}\text { Physical } \\
\text { Capital }\end{array}$ & $\begin{array}{c}\text { R\&D } \\
\text { Capital }\end{array}$ & $\begin{array}{l}\text { Interm. } \\
\text { Inputs }\end{array}$ \\
\hline \multirow[t]{4}{*}{30} & Labor & $\begin{array}{l}-0.7206 \\
(0.0088)\end{array}$ & $\begin{array}{c}0.2156 \\
(0.0147)\end{array}$ & $\begin{array}{c}0.0931 \\
(0.0053)\end{array}$ & $\begin{array}{c}0.4119 \\
(0.0103)\end{array}$ \\
\hline & Phys. Capital & $\begin{array}{c}0.4502 \\
(0.0294)\end{array}$ & $\begin{array}{l}-0.8662 \\
(0.0107)\end{array}$ & $\begin{array}{c}0.0405 \\
(0.0171)\end{array}$ & $\begin{array}{c}0.3755 \\
(0.0192)\end{array}$ \\
\hline & R\&D Capital & $\begin{array}{c}1.3457 \\
(0.1552)\end{array}$ & $\begin{array}{c}0.2805 \\
(0.1344)\end{array}$ & $\begin{array}{l}-0.9807 \\
(0.0014)\end{array}$ & $\begin{array}{l}-0.6455 \\
(0.1441)\end{array}$ \\
\hline & Inter. Inputs & $\begin{array}{c}0.2028 \\
(0.0074)\end{array}$ & $\begin{array}{c}0.0885 \\
(0.0087)\end{array}$ & $\begin{array}{l}-0.0220 \\
(0.0045)\end{array}$ & $\begin{array}{l}-0.2694 \\
(0.0095)\end{array}$ \\
\hline \multirow[t]{4}{*}{32} & Labor & $\begin{array}{l}-0.7131 \\
(0.0089)\end{array}$ & $\begin{array}{c}0.2810 \\
(0.0147)\end{array}$ & $\begin{array}{c}0.0892 \\
(0.0053)\end{array}$ & $\begin{array}{c}0.3428 \\
(0.0103)\end{array}$ \\
\hline & Phys. Capital & $\begin{array}{c}0.4005 \\
(0.0184)\end{array}$ & $\begin{array}{l}-0.7987 \\
(0.0107)\end{array}$ & $\begin{array}{c}0.0315 \\
(0.0117)\end{array}$ & $\begin{array}{c}0.3667 \\
(0.0145)\end{array}$ \\
\hline & R\&D Capital & $\begin{array}{c}1.4708 \\
(0.1669)\end{array}$ & $\begin{array}{c}0.3642 \\
(0.1489)\end{array}$ & $\begin{array}{l}-0.9826 \\
(0.0013)\end{array}$ & $\begin{array}{l}-0.8524 \\
(0.1596)\end{array}$ \\
\hline & Inter. Inputs & $\begin{array}{c}0.1990 \\
(0.0075)\end{array}$ & $\begin{array}{c}0.1493 \\
(0.0085)\end{array}$ & $\begin{array}{l}-0.0300 \\
(0.0052)\end{array}$ & $\begin{array}{l}-0.3183 \\
(0.0101)\end{array}$ \\
\hline \multirow[t]{4}{*}{33} & Labor & $\begin{array}{l}-0.7767 \\
(0.0112)\end{array}$ & $\begin{array}{c}0.2781 \\
(0.0203)\end{array}$ & $\begin{array}{c}0.1093 \\
(0.0054)\end{array}$ & $\begin{array}{c}0.3894 \\
(0.0128)\end{array}$ \\
\hline & Phys. Capital & $\begin{array}{c}0.3534 \\
(0.0241)\end{array}$ & $\begin{array}{l}-0.8243 \\
(0.0134)\end{array}$ & $\begin{array}{c}0.0331 \\
(0.0131)\end{array}$ & $\begin{array}{c}0.4378 \\
(0.0156)\end{array}$ \\
\hline & R\&D Capital & $\begin{array}{c}1.4358 \\
(0.1700)\end{array}$ & $\begin{array}{c}0.3425 \\
(0.1540)\end{array}$ & $\begin{array}{l}-0.9830 \\
(0.0014)\end{array}$ & $\begin{array}{l}-0.7953 \\
(0.1531)\end{array}$ \\
\hline & Inter. Inputs & $\begin{array}{c}0.1488 \\
(0.0093)\end{array}$ & $\begin{array}{c}0.1317 \\
(0.0106)\end{array}$ & $\begin{array}{l}-0.0231 \\
(0.0043)\end{array}$ & $\begin{array}{l}-0.2574 \\
(0.0098)\end{array}$ \\
\hline \multirow[t]{4}{*}{34} & Labor & $\begin{array}{l}-0.6841 \\
(0.0109)\end{array}$ & $\begin{array}{c}0.1662 \\
(0.0159)\end{array}$ & $\begin{array}{c}0.0768 \\
(0.0046)\end{array}$ & $\begin{array}{c}0.4411 \\
(0.0109)\end{array}$ \\
\hline & Phys. Capital & $\begin{array}{c}0.5596 \\
(0.0531)\end{array}$ & $\begin{array}{l}-0.9062 \\
(0.0130)\end{array}$ & $\begin{array}{c}0.0418 \\
(0.0224)\end{array}$ & $\begin{array}{c}0.3048 \\
(0.0294)\end{array}$ \\
\hline & R\&D Capital & $\begin{array}{c}2.0927 \\
(0.3063)\end{array}$ & $\begin{array}{c}0.3383 \\
(0.2183)\end{array}$ & $\begin{array}{l}-0.9884 \\
(0.0013)\end{array}$ & $\begin{array}{l}-1.4426 \\
(0.2885)\end{array}$ \\
\hline & Inter. Inputs & $\begin{array}{c}0.2408 \\
(0.0091)\end{array}$ & $\begin{array}{c}0.0494 \\
(0.0105)\end{array}$ & $\begin{array}{l}-0.0289 \\
(0.0045)\end{array}$ & $\begin{array}{l}-0.2613 \\
(0.0100)\end{array}$ \\
\hline
\end{tabular}


Table 5 (cont'd)

\begin{tabular}{|c|c|c|c|c|c|}
\hline Code & Demand & Labor & $\begin{array}{r}\text { Physical } \\
\text { Capital }\end{array}$ & $\begin{array}{c}\text { R\&D } \\
\text { Capital }\end{array}$ & $\begin{array}{l}\text { Interm. } \\
\text { Inputs }\end{array}$ \\
\hline \multirow[t]{4}{*}{35} & Labor & $\begin{array}{l}-0.6758 \\
(0.0111)\end{array}$ & $\begin{array}{c}0.1795 \\
(0.0160)\end{array}$ & $\begin{array}{c}0.1025 \\
(0.0045)\end{array}$ & $\begin{array}{c}0.3938 \\
(0.0111)\end{array}$ \\
\hline & Phys. Capital & $\begin{array}{c}0.5339 \\
(0.0432)\end{array}$ & $\begin{array}{l}-0.8910 \\
(0.0132)\end{array}$ & $\begin{array}{c}0.0650 \\
(0.0198)\end{array}$ & $\begin{array}{c}0.2921 \\
(0.0233)\end{array}$ \\
\hline & R\&D Capital & $\begin{array}{c}0.8532 \\
(0.0702)\end{array}$ & $\begin{array}{c}0.1818 \\
(0.0749)\end{array}$ & $\begin{array}{l}-0.9611 \\
(0.0013)\end{array}$ & $\begin{array}{l}-0.0739 \\
(0.0655)\end{array}$ \\
\hline & Inter. Inputs & $\begin{array}{c}0.2418 \\
(0.0091)\end{array}$ & $\begin{array}{c}0.0603 \\
(0.0104)\end{array}$ & $\begin{array}{l}-0.0055 \\
(0.0049)\end{array}$ & $\begin{array}{l}-0.2967 \\
(0.0102)\end{array}$ \\
\hline \multirow[t]{4}{*}{36} & Labor & $\begin{array}{l}-0.6734 \\
(0.0106)\end{array}$ & $\begin{array}{c}0.1598 \\
(0.0155)\end{array}$ & $\begin{array}{c}0.1202 \\
(0.0047)\end{array}$ & $\begin{array}{c}0.3934 \\
(0.0109)\end{array}$ \\
\hline & Phys. Capital & $\begin{array}{c}0.5811 \\
(0.0553)\end{array}$ & $\begin{array}{l}-0.9102 \\
(0.0126)\end{array}$ & $\begin{array}{c}0.0887 \\
(0.0234)\end{array}$ & $\begin{array}{c}0.2403 \\
(0.0308)\end{array}$ \\
\hline & R\&D Capital & $\begin{array}{c}0.6871 \\
(0.0489)\end{array}$ & $\begin{array}{c}0.1394 \\
(0.0547)\end{array}$ & $\begin{array}{l}-0.9429 \\
(0.0013)\end{array}$ & $\begin{array}{c}0.1163 \\
(0.0466)\end{array}$ \\
\hline & Inter. Inputs & $\begin{array}{c}0.2440 \\
(0.0087)\end{array}$ & $\begin{array}{c}0.0410 \\
(0.0099)\end{array}$ & $\begin{array}{c}0.0126 \\
(0.0048)\end{array}$ & $\begin{array}{l}-0.2977 \\
(0.0099)\end{array}$ \\
\hline \multirow[t]{4}{*}{37} & Labor & $\begin{array}{l}-0.7523 \\
(0.0122)\end{array}$ & $\begin{array}{c}0.1892 \\
(0.0198)\end{array}$ & $\begin{array}{c}0.1233 \\
(0.0048)\end{array}$ & $\begin{array}{c}0.4397 \\
(0.0120)\end{array}$ \\
\hline & Phys. Capital & $\begin{array}{c}0.4836 \\
(0.0540)\end{array}$ & $\begin{array}{l}-0.9031 \\
(0.0144)\end{array}$ & $\begin{array}{c}0.0694 \\
(0.0211)\end{array}$ & $\begin{array}{c}0.3501 \\
(0.0286)\end{array}$ \\
\hline & R\&D Capital & $\begin{array}{c}0.7610 \\
(0.0679)\end{array}$ & $\begin{array}{c}0.1675 \\
(0.0748)\end{array}$ & $\begin{array}{l}-0.9599 \\
(0.0013)\end{array}$ & $\begin{array}{c}0.0314 \\
(0.0681)\end{array}$ \\
\hline & Inter. Inputs & $\begin{array}{c}0.1771 \\
(0.0104)\end{array}$ & $\begin{array}{c}0.0551 \\
(0.0118)\end{array}$ & $\begin{array}{c}0.0020 \\
(0.0044)\end{array}$ & $\begin{array}{l}-0.2343 \\
(0.0107)\end{array}$ \\
\hline \multirow[t]{4}{*}{38} & Labor & $\begin{array}{l}-0.6348 \\
(0.0083)\end{array}$ & $\begin{array}{c}0.1582 \\
(0.0126)\end{array}$ & $\begin{array}{c}0.1185 \\
(0.0047)\end{array}$ & $\begin{array}{c}0.3581 \\
(0.0096)\end{array}$ \\
\hline & Phys. Capital & $\begin{array}{c}0.6043 \\
(0.0444)\end{array}$ & $\begin{array}{l}-0.9044 \\
(0.0102)\end{array}$ & $\begin{array}{c}0.0917 \\
(0.0231)\end{array}$ & $\begin{array}{c}0.2084 \\
(0.0272)\end{array}$ \\
\hline & R\&D Capital & $\begin{array}{c}0.6970 \\
(0.0435)\end{array}$ & $\begin{array}{c}0.1413 \\
(0.0487)\end{array}$ & $\begin{array}{l}-0.9379 \\
(0.0013)\end{array}$ & $\begin{array}{c}0.0996 \\
(0.0413)\end{array}$ \\
\hline & Inter. Inputs & $\begin{array}{c}0.2741 \\
(0.0071)\end{array}$ & $\begin{array}{c}0.0418 \\
(0.0080)\end{array}$ & $\begin{array}{c}0.0130 \\
(0.0051)\end{array}$ & $\begin{array}{l}-0.3288 \\
(0.0100)\end{array}$ \\
\hline
\end{tabular}


Table 5 (cont'd)

\begin{tabular}{|c|c|c|c|c|c|}
\hline Code & Demand & Labor & $\begin{array}{r}\text { Physical } \\
\text { Capital }\end{array}$ & $\begin{array}{l}\text { R\&D } \\
\text { Capital }\end{array}$ & $\begin{array}{l}\text { Interm. } \\
\text { Inputs }\end{array}$ \\
\hline \multirow[t]{4}{*}{40} & Labor & $\begin{array}{l}-0.6613 \\
(0.0111)\end{array}$ & $\begin{array}{c}0.1600 \\
(0.0157)\end{array}$ & $\begin{array}{c}0.0682 \\
(0.0044)\end{array}$ & $\begin{array}{c}0.4331 \\
(0.0110)\end{array}$ \\
\hline & Phys. Capital & $\begin{array}{c}0.5857 \\
(0.0551)\end{array}$ & $\begin{array}{l}-0.9075 \\
(0.0134)\end{array}$ & $\begin{array}{c}0.0380 \\
(0.0226)\end{array}$ & $\begin{array}{c}0.2837 \\
(0.0306)\end{array}$ \\
\hline & R\&D Capital & $\begin{array}{c}3.1322 \\
(0.6803)\end{array}$ & $\begin{array}{c}0.4769 \\
(0.3362)\end{array}$ & $\begin{array}{l}-0.9926 \\
(0.0015)\end{array}$ & $\begin{array}{l}-2.6165 \\
(0.6849)\end{array}$ \\
\hline & Inter. Inputs & $\begin{array}{c}0.2612 \\
(0.0093)\end{array}$ & $\begin{array}{c}0.0468 \\
(0.0108)\end{array}$ & $\begin{array}{l}-0.0344 \\
(0.0047)\end{array}$ & $\begin{array}{l}-0.2736 \\
(0.0103)\end{array}$ \\
\hline \multirow[t]{4}{*}{41} & Labor & $\begin{array}{l}-0.7146 \\
(0.0107)\end{array}$ & $\begin{array}{c}0.1652 \\
(0.0169)\end{array}$ & $\begin{array}{c}0.0838 \\
(0.0050)\end{array}$ & $\begin{array}{c}0.4655 \\
(0.0116)\end{array}$ \\
\hline & Phys. Capital & $\begin{array}{c}0.5539 \\
(0.0604)\end{array}$ & $\begin{array}{l}-0.9148 \\
(0.0128)\end{array}$ & $\begin{array}{c}0.0449 \\
(0.0245)\end{array}$ & $\begin{array}{c}0.3160 \\
(0.0339)\end{array}$ \\
\hline & R\&D Capital & $\begin{array}{c}2.0541 \\
(0.2986)\end{array}$ & $\begin{array}{c}0.3285 \\
(0.2126)\end{array}$ & $\begin{array}{l}-0.9884 \\
(0.0014)\end{array}$ & $\begin{array}{l}-1.3943 \\
(0.2489)\end{array}$ \\
\hline & Inter. Inputs & $\begin{array}{c}0.2151 \\
(0.0089)\end{array}$ & $\begin{array}{c}0.0436 \\
(0.0103)\end{array}$ & $\begin{array}{l}-0.0263 \\
(0.0038)\end{array}$ & $\begin{array}{l}-0.2323 \\
(0.0094)\end{array}$ \\
\hline \multirow[t]{4}{*}{42} & Labor & $\begin{array}{l}-0.7035 \\
(0.0097)\end{array}$ & $\begin{array}{c}0.1828 \\
(0.0153)\end{array}$ & $\begin{array}{c}0.0783 \\
(0.0050)\end{array}$ & $\begin{array}{c}0.4424 \\
(0.0105)\end{array}$ \\
\hline & Phys. Capital & $\begin{array}{c}0.5129 \\
(0.0418)\end{array}$ & $\begin{array}{l}-0.8943 \\
(0.0116)\end{array}$ & $\begin{array}{c}0.0357 \\
(0.0207)\end{array}$ & $\begin{array}{c}0.3458 \\
(0.0241)\end{array}$ \\
\hline & R\&D Capital & $\begin{array}{c}2.6309 \\
(0.4494)\end{array}$ & $\begin{array}{c}0.4269 \\
(0.2815)\end{array}$ & $\begin{array}{l}-0.9912 \\
(0.0013)\end{array}$ & $\begin{array}{l}-2.0666 \\
(0.4367)\end{array}$ \\
\hline & Inter. Inputs & $\begin{array}{c}0.2227 \\
(0.0081)\end{array}$ & $\begin{array}{c}0.0620 \\
(0.0093)\end{array}$ & $\begin{array}{l}-0.0310 \\
(0.0043)\end{array}$ & $\begin{array}{l}-0.2538 \\
(0.0095)\end{array}$ \\
\hline
\end{tabular}


Table 6: Elasticitles of Incremental RoD Tax Credit (Mean Values 1981-1988; Stand. Error in Parethesis)

\begin{tabular}{|c|c|c|c|c|c|}
\hline Code & Cost & Labor & $\begin{array}{r}\text { Physical } \\
\text { Capital }\end{array}$ & $\begin{array}{l}\text { R\&D } \\
\text { Capital }\end{array}$ & rm. \\
\hline 20 & $\begin{array}{l}-0.0003 \\
(0.0001)\end{array}$ & $\begin{array}{l}-0.0113 \\
(0.0048)\end{array}$ & $\begin{array}{l}-0.0035 \\
(0.0015)\end{array}$ & $\begin{array}{c}0.0712 \\
(0.0302)\end{array}$ & $\begin{array}{c}0.0013 \\
(0.0006)\end{array}$ \\
\hline 26 & $\begin{array}{l}-0.0007 \\
(0.0003)\end{array}$ & $\begin{array}{l}-0.0079 \\
(0.0034)\end{array}$ & $\begin{array}{l}-0.0021 \\
(0.0009)\end{array}$ & $\begin{array}{c}0.0710 \\
(0.0302)\end{array}$ & $\begin{array}{c}0.0019 \\
(0.0008)\end{array}$ \\
\hline 28 & $\begin{array}{l}-0.0037 \\
(0.0015)\end{array}$ & $\begin{array}{l}-0.0117 \\
(0.0050)\end{array}$ & $\begin{array}{l}-0.0043 \\
(0.0018)\end{array}$ & $\begin{array}{c}0.0688 \\
(0.0292)\end{array}$ & $\begin{array}{l}-0.0004 \\
(0.0002)\end{array}$ \\
\hline 29 & $\begin{array}{l}-0.0012 \\
(0.0004)\end{array}$ & $\begin{array}{l}-0.0448 \\
(0.0190)\end{array}$ & $\begin{array}{l}-0.0025 \\
(0.0011)\end{array}$ & $\begin{array}{c}0.0715 \\
(0.0304)\end{array}$ & $\begin{array}{c}0.0014 \\
(0.0006)\end{array}$ \\
\hline 30 & $\begin{array}{l}-0.0013 \\
(0.0006)\end{array}$ & $\begin{array}{l}-0.0067 \\
(0.0028)\end{array}$ & $\begin{array}{l}-0.0029 \\
(0.0012)\end{array}$ & $\begin{array}{c}0.0707 \\
(0.0300)\end{array}$ & $\begin{array}{c}0.0016 \\
(0.0007)\end{array}$ \\
\hline 32 & $\begin{array}{l}-0.0012 \\
(0.0005)\end{array}$ & $\begin{array}{l}-0.0064 \\
(0.0027)\end{array}$ & $\begin{array}{l}-0.0023 \\
(0.0010)\end{array}$ & $\begin{array}{c}0.0708 \\
(0.0301)\end{array}$ & $\begin{array}{c}0.0022 \\
(0.0009)\end{array}$ \\
\hline 33 & $\begin{array}{l}-0.0007 \\
(0.0003)\end{array}$ & $\begin{array}{l}-0.0079 \\
(0.0033)\end{array}$ & $\begin{array}{l}-0.0024 \\
(0.0010)\end{array}$ & $\begin{array}{c}0.0708 \\
(0.0301)\end{array}$ & $\begin{array}{c}0.0017 \\
(0.0007)\end{array}$ \\
\hline 34 & $\begin{array}{l}-0.0006 \\
(0.0003)\end{array}$ & $\begin{array}{l}-0.0055 \\
(0.0024)\end{array}$ & $\begin{array}{l}-0.0030 \\
(0.0013)\end{array}$ & $\begin{array}{c}0.0712 \\
(0.0302)\end{array}$ & $\begin{array}{c}0.0021 \\
(0.0009)\end{array}$ \\
\hline 35 & $\begin{array}{l}-0.0038 \\
(0.0015)\end{array}$ & $\begin{array}{l}-0.0074 \\
(0.0031)\end{array}$ & $\begin{array}{l}-0.0047 \\
(0.0020)\end{array}$ & $\begin{array}{c}0.0692 \\
(0.0294)\end{array}$ & $\begin{array}{c}0.0004 \\
(0.0002)\end{array}$ \\
\hline 36 & $\begin{array}{l}-0.0047 \\
(0.0020)\end{array}$ & $\begin{array}{l}-0.0087 \\
(0.0037)\end{array}$ & $\begin{array}{l}-0.0064 \\
(0.0027)\end{array}$ & $\begin{array}{c}0.0679 \\
(0.0288)\end{array}$ & $\begin{array}{l}-0.0009 \\
(0.0004)\end{array}$ \\
\hline 37 & $\begin{array}{l}-0.0040 \\
(0.0018)\end{array}$ & $\begin{array}{l}-0.0089 \\
(0.0038)\end{array}$ & $\begin{array}{l}-0.0050 \\
(0.0021)\end{array}$ & $\begin{array}{c}0.0692 \\
(0.0294)\end{array}$ & $\begin{array}{l}-0.0001 \\
(0.0001)\end{array}$ \\
\hline 38 & $\begin{array}{l}-0.0065 \\
(0.0027)\end{array}$ & $\begin{array}{l}-0.0085 \\
(0.0036)\end{array}$ & $\begin{array}{l}-0.0066 \\
(0.0028)\end{array}$ & $\begin{array}{c}0.0676 \\
(0.0287)\end{array}$ & $\begin{array}{l}-0.0009 \\
(0.0004)\end{array}$ \\
\hline 40 & $\begin{array}{l}-0.0004 \\
(0.0002)\end{array}$ & $\begin{array}{l}-0.0049 \\
(0.0021)\end{array}$ & $\begin{array}{l}-0.0027 \\
(0.0012)\end{array}$ & $\begin{array}{c}0.0715 \\
(0.0304)\end{array}$ & $\begin{array}{c}0.0025 \\
(0.0011)\end{array}$ \\
\hline 41 & $\begin{array}{l}-0.0002 \\
(0.0001)\end{array}$ & $\begin{array}{l}-0.0060 \\
(0.0026)\end{array}$ & $\begin{array}{l}-0.0032 \\
(0.0014)\end{array}$ & $\begin{array}{c}0.0712 \\
(0.0302)\end{array}$ & $\begin{array}{c}0.0019 \\
(0.0008)\end{array}$ \\
\hline 42 & $\begin{array}{l}-0.0002 \\
(0.0001)\end{array}$ & $\begin{array}{l}-0.0056 \\
(0.0024)\end{array}$ & $\begin{array}{l}-0.0026 \\
(0.0011)\end{array}$ & $\begin{array}{c}0.0714 \\
(0.0303)\end{array}$ & $\begin{array}{c}0.0022 \\
(0.0009)\end{array}$ \\
\hline
\end{tabular}


Table 7: Elasticities of R\&D Expensing (Mean Values 1981-1988;Stand. Error in Parethesis)

\begin{tabular}{|c|c|c|c|c|c|}
\hline Code & Cost & Labor & $\begin{array}{r}\text { Physical } \\
\text { Capital }\end{array}$ & $\begin{array}{c}\text { R\&D } \\
\text { Capital }\end{array}$ & $\begin{array}{l}\text { Interm. } \\
\text { Inputs }\end{array}$ \\
\hline 20 & $\begin{array}{l}-0.0037 \\
(0.0010)\end{array}$ & $\begin{array}{l}-0.1223 \\
(0.0315)\end{array}$ & $\begin{array}{l}-0.0382 \\
(0.0099)\end{array}$ & $\begin{array}{c}0.7718 \\
(0.1990)\end{array}$ & $\begin{array}{c}0.0145 \\
(0.0037)\end{array}$ \\
\hline 26 & $\begin{array}{l}-0.0080 \\
(0.0024)\end{array}$ & $\begin{array}{l}-0.0861 \\
(0.0222)\end{array}$ & $\begin{array}{l}-0.0226 \\
(0.0058)\end{array}$ & $\begin{array}{c}0.7702 \\
(0.1986)\end{array}$ & $\begin{array}{c}0.0205 \\
(0.0053)\end{array}$ \\
\hline 28 & $\begin{array}{l}-0.0404 \\
(0.0090)\end{array}$ & $\begin{array}{l}-0.1265 \\
(0.0326)\end{array}$ & $\begin{array}{l}-0.0467 \\
(0.0120)\end{array}$ & $\begin{array}{c}0.7458 \\
(0.1923)\end{array}$ & $\begin{array}{l}-0.0040 \\
(0.0010)\end{array}$ \\
\hline 29 & $\begin{array}{l}-0.0127 \\
(0.0016)\end{array}$ & $\begin{array}{l}-0.4857 \\
(0.1252)\end{array}$ & $\begin{array}{l}-0.0274 \\
(0.0071)\end{array}$ & $\begin{array}{c}0.7750 \\
(0.1998)\end{array}$ & $\begin{array}{c}0.0153 \\
(0.0039)\end{array}$ \\
\hline 30 & $\begin{array}{l}-0.0140 \\
(0.0048)\end{array}$ & $\begin{array}{l}-0.0727 \\
(0.0187)\end{array}$ & $\begin{array}{l}-0.0316 \\
(0.0082)\end{array}$ & $\begin{array}{c}0.7660 \\
(0.1975)\end{array}$ & $\begin{array}{c}0.0172 \\
(0.0044)\end{array}$ \\
\hline 32 & $\begin{array}{l}-0.0127 \\
(0.0026)\end{array}$ & $\begin{array}{l}-0.0697 \\
(0.0180)\end{array}$ & $\begin{array}{l}-0.0246 \\
(0.0063)\end{array}$ & $\begin{array}{c}0.7675 \\
(0.1979)\end{array}$ & $\begin{array}{c}0.0234 \\
(0.0060)\end{array}$ \\
\hline 33 & $\begin{array}{l}-0.0076 \\
(0.0020)\end{array}$ & $\begin{array}{l}-0.0854 \\
(0.0220)\end{array}$ & $\begin{array}{l}-0.0259 \\
(0.0067)\end{array}$ & $\begin{array}{c}0.7679 \\
(0.1980)\end{array}$ & $\begin{array}{c}0.0181 \\
(0.0047)\end{array}$ \\
\hline 34 & $\begin{array}{l}-0.0068 \\
(0.0019)\end{array}$ & $\begin{array}{l}-0.0600 \\
(0.0155)\end{array}$ & $\begin{array}{l}-0.0327 \\
(0.0084)\end{array}$ & $\begin{array}{c}0.7721 \\
(0.1991)\end{array}$ & $\begin{array}{c}0.0226 \\
(0.0058)\end{array}$ \\
\hline 35 & $\begin{array}{l}-0.0415 \\
(0.0088)\end{array}$ & $\begin{array}{l}-0.0801 \\
(0.0206)\end{array}$ & $\begin{array}{l}-0.0507 \\
(0.0131)\end{array}$ & $\begin{array}{c}0.7507 \\
(0.1936)\end{array}$ & $\begin{array}{c}0.0043 \\
(0.0011)\end{array}$ \\
\hline 36 & $\begin{array}{l}-0.0515 \\
(0.0141)\end{array}$ & $\begin{array}{l}-0.0939 \\
(0.0242)\end{array}$ & $\begin{array}{l}-0.0693 \\
(0.0179)\end{array}$ & $\begin{array}{c}0.7365 \\
(0.1899)\end{array}$ & $\begin{array}{l}-0.0099 \\
(0.0025)\end{array}$ \\
\hline 37 & $\begin{array}{l}-0.0430 \\
(0.0132)\end{array}$ & $\begin{array}{l}-0.0963 \\
(0.0248)\end{array}$ & $\begin{array}{l}-0.0542 \\
(0.0140)\end{array}$ & $\begin{array}{c}0.7498 \\
(0.1933)\end{array}$ & $\begin{array}{l}-0.0016 \\
(0.0004)\end{array}$ \\
\hline 38 & $\begin{array}{l}-0.0707 \\
(0.0170)\end{array}$ & $\begin{array}{l}-0.0926 \\
(0.0239)\end{array}$ & $\begin{array}{l}-0.0717 \\
(0.0185)\end{array}$ & $\begin{array}{c}0.7326 \\
(0.1889)\end{array}$ & $\begin{array}{l}-0.0101 \\
(0.0026)\end{array}$ \\
\hline 40 & $\begin{array}{l}-0.0043 \\
(0.0011)\end{array}$ & $\begin{array}{l}-0.0533 \\
(0.0137)\end{array}$ & $\begin{array}{l}-0.0297 \\
(0.0077)\end{array}$ & $\begin{array}{c}0.7754 \\
(0.1999)\end{array}$ & $\begin{array}{c}0.0269 \\
(0.0069)\end{array}$ \\
\hline 41 & $\begin{array}{l}-0.0020 \\
(0.0005)\end{array}$ & $\begin{array}{l}-0.0655 \\
(0.0169)\end{array}$ & $\begin{array}{l}-0.0351 \\
(0.0091)\end{array}$ & $\begin{array}{c}0.7720 \\
(0.1991)\end{array}$ & $\begin{array}{c}0.0205 \\
(0.0053)\end{array}$ \\
\hline 42 & $\begin{array}{l}-0.0026 \\
(0.0009)\end{array}$ & $\begin{array}{l}-0.0612 \\
(0.0158)\end{array}$ & $\begin{array}{l}-0.0279 \\
(0.0072)\end{array}$ & $\begin{array}{c}0.7742 \\
(0.1996)\end{array}$ & $\begin{array}{c}0.0242 \\
(0.0062)\end{array}$ \\
\hline
\end{tabular}


Table 8:Elastlcities of Publicly Funded R\&D

(1982 Values; Stand. Error in Parenthesis)

\begin{tabular}{|c|c|c|c|c|c|c|}
\hline \multicolumn{2}{|l|}{ Code } & \multirow{2}{*}{$\begin{array}{c}\text { Cost } \\
-0.0038 \\
(0.0013)\end{array}$} & \multirow{2}{*}{$\begin{array}{l}\text { Labor } \\
\begin{array}{l}-0.0045 \\
(0.0017)\end{array}\end{array}$} & \multirow{2}{*}{$\begin{array}{l}\text { Physical } \\
\text { Capital } \\
\\
(0.0159 \\
(0.0033)\end{array}$} & \multirow{2}{*}{$\begin{array}{c}\text { R\&D } \\
\text { Capital } \\
0.0468 \\
(0.0202)\end{array}$} & \multirow{2}{*}{$\begin{array}{l}\text { Interm. } \\
\text { Inputs } \\
\\
-0.0026 \\
(0.0014)\end{array}$} \\
\hline 20 & Internal & & & & & \\
\hline & External & $\begin{array}{l}-0.2168 \\
(0.0586)\end{array}$ & $\begin{array}{l}-0.1935 \\
(0.0609)\end{array}$ & $\begin{array}{c}0.1836 \\
(0.0723)\end{array}$ & $\begin{array}{l}-1.8003 \\
(0.3729)\end{array}$ & $\begin{array}{l}-0.2582 \\
(0.0589)\end{array}$ \\
\hline & Total & $\begin{array}{l}-0.2206 \\
(0.0592)\end{array}$ & $\begin{array}{l}-0.1979 \\
(0.0614)\end{array}$ & $\begin{array}{c}0.1677 \\
(0.0725)\end{array}$ & $\begin{array}{l}-1.7536 \\
(0.3696)\end{array}$ & $\begin{array}{l}-0.2608 \\
(0.0594)\end{array}$ \\
\hline 26 & Internal & $\begin{array}{l}-0.0015 \\
(0.0006)\end{array}$ & $\begin{array}{l}-0.0017 \\
(0.0006)\end{array}$ & $\begin{array}{l}-0.0038 \\
(0.0008)\end{array}$ & $\begin{array}{c}0.0076 \\
(0.0037)\end{array}$ & $\begin{array}{l}-0.0008 \\
(0.0006)\end{array}$ \\
\hline & External & $\begin{array}{l}-0.2249 \\
(0.0586)\end{array}$ & $\begin{array}{l}-0.2094 \\
(0.0595)\end{array}$ & $\begin{array}{l}-0.0439 \\
(0.0611)\end{array}$ & $\begin{array}{l}-0.8978 \\
(0.1713)\end{array}$ & $\begin{array}{l}-0.2795 \\
(0.0591)\end{array}$ \\
\hline & Total & $\begin{array}{l}-0.2263 \\
(0.0587)\end{array}$ & $\begin{array}{l}-0.2111 \\
(0.0596)\end{array}$ & $\begin{array}{l}-0.0476 \\
(0.0611)\end{array}$ & $\begin{array}{l}-0.8902 \\
(0.1707)\end{array}$ & $\begin{array}{l}-0.2803 \\
(0.0591)\end{array}$ \\
\hline 28 & Internal & $\begin{array}{l}-0.0719 \\
(0.0259)\end{array}$ & $\begin{array}{l}-0.0825 \\
(0.0300)\end{array}$ & $\begin{array}{l}-0.1810 \\
(0.0373)\end{array}$ & $\begin{array}{c}0.0187 \\
(0.0499)\end{array}$ & $\begin{array}{l}-0.0407 \\
(0.0267)\end{array}$ \\
\hline & External & $\begin{array}{l}-0.1947 \\
(0.0553)\end{array}$ & $\begin{array}{l}-0.1756 \\
(0.0569)\end{array}$ & $\begin{array}{l}-0.0094 \\
(0.0582)\end{array}$ & $\begin{array}{l}-0.3407 \\
(0.0684)\end{array}$ & $\begin{array}{l}-0.2488 \\
(0.0558)\end{array}$ \\
\hline & Total & $\begin{array}{l}-0.2666 \\
(0.0625)\end{array}$ & $\begin{array}{l}-0.2581 \\
(0.0650)\end{array}$ & $\begin{array}{l}-0.1904 \\
(0.0691)\end{array}$ & $\begin{array}{l}-0.3220 \\
(0.0818)\end{array}$ & $\begin{array}{l}-0.2895 \\
(0.0632)\end{array}$ \\
\hline 29 & Internal & $\begin{array}{l}-0.0440 \\
(0.0160)\end{array}$ & $\begin{array}{l}-0.0715 \\
(0.0469)\end{array}$ & $\begin{array}{l}-0.2089 \\
(0.0438)\end{array}$ & $\begin{array}{c}0.1787 \\
(0.0933)\end{array}$ & $\begin{array}{l}-0.0310 \\
(0.0162)\end{array}$ \\
\hline & External & $\begin{array}{l}-0.1213 \\
(0.0566)\end{array}$ & $\begin{array}{l}-0.0411 \\
(0.0848)\end{array}$ & $\begin{array}{c}0.3328 \\
(0.0739)\end{array}$ & $\begin{array}{l}-0.7031 \\
(0.1511)\end{array}$ & $\begin{array}{l}-0.1579 \\
(0.0569)\end{array}$ \\
\hline & Total & $\begin{array}{l}-0.1653 \\
(0.0603)\end{array}$ & $\begin{array}{l}-0.1126 \\
(0.0918)\end{array}$ & $\begin{array}{c}0.1239 \\
(0.0825)\end{array}$ & $\begin{array}{l}-0.5244 \\
(0.1633)\end{array}$ & $\begin{array}{l}-0.1889 \\
(0.0605)\end{array}$ \\
\hline 30 & Internal & $\begin{array}{l}-0.0551 \\
(0.0210)\end{array}$ & $\begin{array}{l}-0.0605 \\
(0.0221)\end{array}$ & $\begin{array}{l}-0.1623 \\
(0.0340)\end{array}$ & $\begin{array}{c}0.1277 \\
(0.0805)\end{array}$ & $\begin{array}{l}-0.0280 \\
(0.0217)\end{array}$ \\
\hline & External & $\begin{array}{l}-0.2385 \\
(0.0560)\end{array}$ & $\begin{array}{l}-0.2266 \\
(0.0564)\end{array}$ & $\begin{array}{l}-0.0140 \\
(0.0603)\end{array}$ & $\begin{array}{l}-0.6016 \\
(0.1064)\end{array}$ & $\begin{array}{l}-0.2963 \\
(0.0565)\end{array}$ \\
\hline & Total & $\begin{array}{l}-0.2936 \\
(0.0612)\end{array}$ & $\begin{array}{l}-0.2871 \\
(0.0617)\end{array}$ & $\begin{array}{l}-0.1763 \\
(0.0690)\end{array}$ & $\begin{array}{l}-0.4739 \\
(0.1233)\end{array}$ & $\begin{array}{l}-0.3243 \\
(0.0617)\end{array}$ \\
\hline
\end{tabular}


Table 8 (cont'd)

\begin{tabular}{|c|c|c|c|c|c|c|}
\hline Code & & Cost & Labor & $\begin{array}{l}\text { Physical } \\
\text { Capital }\end{array}$ & $\begin{array}{l}\text { R\&D } \\
\text { Capital }\end{array}$ & $\begin{array}{l}\text { Interm. } \\
\text { Inputs }\end{array}$ \\
\hline \multirow[t]{3}{*}{32} & Internal & $\begin{array}{l}-0.0202 \\
(0.0078)\end{array}$ & $\begin{array}{l}-0.0221 \\
(0.0082)\end{array}$ & $\begin{array}{l}-0.0488 \\
(0.0106)\end{array}$ & $\begin{array}{c}0.0682 \\
(0.0377)\end{array}$ & $\begin{array}{l}-0.0087 \\
(0.0082)\end{array}$ \\
\hline & External & $\begin{array}{l}-0.1464 \\
(0.0587)\end{array}$ & $\begin{array}{l}-0.1348 \\
(0.0592)\end{array}$ & $\begin{array}{c}0.0144 \\
(0.0606)\end{array}$ & $\begin{array}{l}-0.6172 \\
(0.1293)\end{array}$ & $\begin{array}{l}-0.2121 \\
(0.0594)\end{array}$ \\
\hline & Total & $\begin{array}{l}-0.1666 \\
(0.0603)\end{array}$ & $\begin{array}{l}-0.1569 \\
(0.0607)\end{array}$ & $\begin{array}{l}-0.0344 \\
(0.0623)\end{array}$ & $\begin{array}{l}-0.5489 \\
(0.1290)\end{array}$ & $\begin{array}{l}-0.2208 \\
(0.0609)\end{array}$ \\
\hline \multirow[t]{3}{*}{33} & Internal & $\begin{array}{l}-0.0395 \\
(0.0150)\end{array}$ & $\begin{array}{l}-0.0442 \\
(0.0164)\end{array}$ & $\begin{array}{l}-0.0919 \\
(0.0196)\end{array}$ & $\begin{array}{c}0.2225 \\
(0.1081)\end{array}$ & $\begin{array}{l}-0.0197 \\
(0.0157)\end{array}$ \\
\hline & External & $\begin{array}{l}-0.0271 \\
(0.0555)\end{array}$ & $\begin{array}{l}-0.0125 \\
(0.0564)\end{array}$ & $\begin{array}{c}0.1263 \\
(0.0572)\end{array}$ & $\begin{array}{l}-0.7556 \\
(0.1821)\end{array}$ & $\begin{array}{l}-0.0865 \\
(0.0562)\end{array}$ \\
\hline & Total & $\begin{array}{l}-0.0667 \\
(0.0581)\end{array}$ & $\begin{array}{l}-0.0568 \\
(0.0588)\end{array}$ & $\begin{array}{c}0.0344 \\
(0.0608)\end{array}$ & $\begin{array}{l}-0.5332 \\
(0.1940)\end{array}$ & $\begin{array}{l}-0.1062 \\
(0.0586)\end{array}$ \\
\hline \multirow[t]{3}{*}{34} & Internal & $\begin{array}{l}-0.0319 \\
(0.0120)\end{array}$ & $\begin{array}{l}-0.0347 \\
(0.0125)\end{array}$ & $\begin{array}{l}-0.1029 \\
(0.0211)\end{array}$ & $\begin{array}{c}0.1995 \\
(0.0949)\end{array}$ & $\begin{array}{l}-0.0165 \\
(0.0125)\end{array}$ \\
\hline & External & $\begin{array}{l}-0.1592 \\
(0.0628)\end{array}$ & $\begin{array}{l}-0.1485 \\
(0.0631)\end{array}$ & $\begin{array}{c}0.1006 \\
(0.0679)\end{array}$ & $\begin{array}{l}-0.9634 \\
(0.2011)\end{array}$ & $\begin{array}{l}-0.2168 \\
(0.0633)\end{array}$ \\
\hline & Total & $\begin{array}{l}-0.1912 \\
(0.0661)\end{array}$ & $\begin{array}{l}-0.1832 \\
(0.0663)\end{array}$ & $\begin{array}{l}-0.0023 \\
(0.0723)\end{array}$ & $\begin{array}{l}-0.7639 \\
(0.2067)\end{array}$ & $\begin{array}{l}-0.2333 \\
(0.0665)\end{array}$ \\
\hline \multirow[t]{3}{*}{35} & Internal & $\begin{array}{l}-0.0768 \\
(0.0280)\end{array}$ & $\begin{array}{l}-0.0829 \\
(0.0290)\end{array}$ & $\begin{array}{l}-0.2483 \\
(0.0506)\end{array}$ & $\begin{array}{c}0.0196 \\
(0.0533)\end{array}$ & $\begin{array}{l}-0.0371 \\
(0.0294)\end{array}$ \\
\hline & External & $\begin{array}{l}-0.2916 \\
(0.0563)\end{array}$ & $\begin{array}{l}-0.2814 \\
(0.0566)\end{array}$ & $\begin{array}{l}-0.0217 \\
(0.0626)\end{array}$ & $\begin{array}{l}-0.4353 \\
(0.0689)\end{array}$ & $\begin{array}{l}-0.3551 \\
(0.0570)\end{array}$ \\
\hline & Total & $\begin{array}{l}-0.3683 \\
(0.0652)\end{array}$ & $\begin{array}{l}-0.3642 \\
(0.0656)\end{array}$ & $\begin{array}{l}-0.2700 \\
(0.0799)\end{array}$ & $\begin{array}{l}-0.4157 \\
(0.0849)\end{array}$ & $\begin{array}{l}-0.3922 \\
(0.0660)\end{array}$ \\
\hline \multirow[t]{3}{*}{36} & Internal & $\begin{array}{l}-0.0838 \\
(0.0308)\end{array}$ & $\begin{array}{l}-0.0906 \\
(0.0319)\end{array}$ & $\begin{array}{l}-0.2843 \\
(0.0582)\end{array}$ & $\begin{array}{l}-0.0068 \\
(0.0492)\end{array}$ & $\begin{array}{l}-0.0396 \\
(0.0323)\end{array}$ \\
\hline & External & $\begin{array}{l}-0.2567 \\
(0.0562)\end{array}$ & $\begin{array}{l}-0.2463 \\
(0.0565)\end{array}$ & $\begin{array}{c}0.0301 \\
(0.0634)\end{array}$ & $\begin{array}{l}-0.3611 \\
(0.0640)\end{array}$ & $\begin{array}{l}-0.3210 \\
(0.0568)\end{array}$ \\
\hline & Total & $\begin{array}{l}-0.3405 \\
(0.0653)\end{array}$ & $\begin{array}{l}-0.3369 \\
(0.0659)\end{array}$ & $\begin{array}{l}-0.2542 \\
(0.0839)\end{array}$ & $\begin{array}{l}-0.3679 \\
(0.0789)\end{array}$ & $\begin{array}{l}-0.3606 \\
(0.0663)\end{array}$ \\
\hline
\end{tabular}


Table 8 (cont'd)

\begin{tabular}{|c|c|c|c|c|c|c|}
\hline \multicolumn{2}{|l|}{ Code } & Cost & Labor & $\begin{array}{l}\text { Physical } \\
\text { Capital }\end{array}$ & $\begin{array}{c}R \& D \\
\text { Capital }\end{array}$ & $\begin{array}{l}\text { Interm. } \\
\text { Inputs }\end{array}$ \\
\hline 37 & Internal & $\begin{array}{l}-0.0880 \\
(0.0311)\end{array}$ & $\begin{array}{l}-0.0968 \\
(0.0332)\end{array}$ & $\begin{array}{l}-0.2842 \\
(0.0578)\end{array}$ & $\begin{array}{l}-0.0010 \\
(0.0527)\end{array}$ & $\begin{array}{l}-0.0489 \\
(0.0322)\end{array}$ \\
\hline & External & $\begin{array}{l}-0.1328 \\
(0.0584)\end{array}$ & $\begin{array}{l}-0.1196 \\
(0.0590)\end{array}$ & $\begin{array}{c}0.1448 \\
(0.0649)\end{array}$ & $\begin{array}{l}-0.2495 \\
(0.0675)\end{array}$ & $\begin{array}{l}-0.1891 \\
(0.0589)\end{array}$ \\
\hline & Total & $\begin{array}{l}-0.2207 \\
(0.0678)\end{array}$ & $\begin{array}{l}-0.2163 \\
(0.0689)\end{array}$ & $\begin{array}{l}-0.1394 \\
(0.0853)\end{array}$ & $\begin{array}{l}-0.2505 \\
(0.0837)\end{array}$ & $\begin{array}{l}-0.2380 \\
(0.0685)\end{array}$ \\
\hline \multirow[t]{3}{*}{38} & Internal & $\begin{array}{l}-0.0668 \\
(0.0260)\end{array}$ & $\begin{array}{l}-0.0720 \\
(0.0267)\end{array}$ & $\begin{array}{l}-0.2556 \\
(0.0535)\end{array}$ & $\begin{array}{l}-0.0144 \\
(0.0377)\end{array}$ & $\begin{array}{l}-0.0262 \\
(0.0275)\end{array}$ \\
\hline & External & $\begin{array}{l}-0.2459 \\
(0.0558)\end{array}$ & $\begin{array}{l}-0.2367 \\
(0.0561)\end{array}$ & $\begin{array}{c}0.0734 \\
(0.0648)\end{array}$ & $\begin{array}{l}-0.3300 \\
(0.0616)\end{array}$ & $\begin{array}{l}-0.3160 \\
(0.0565)\end{array}$ \\
\hline & Total & $\begin{array}{l}-0.3127 \\
(0.0634)\end{array}$ & $\begin{array}{l}-0.3086 \\
(0.0637)\end{array}$ & $\begin{array}{l}-0.1821 \\
(0.0821)\end{array}$ & $\begin{array}{l}-0.3444 \\
(0.0719)\end{array}$ & $\begin{array}{l}-0.3421 \\
(0.0644)\end{array}$ \\
\hline \multirow[t]{3}{*}{40} & Internal & $\begin{array}{l}-0.0240 \\
(0.0087)\end{array}$ & $\begin{array}{l}-0.0258 \\
(0.0090)\end{array}$ & $\begin{array}{l}-0.0881 \\
(0.0181)\end{array}$ & $\begin{array}{c}0.2542 \\
(0.1119)\end{array}$ & $\begin{array}{l}-0.0130 \\
(0.0090)\end{array}$ \\
\hline & External & $\begin{array}{l}-0.2545 \\
(0.0677)\end{array}$ & $\begin{array}{l}-0.2445 \\
(0.0680)\end{array}$ & $\begin{array}{c}0.0683 \\
(0.0753)\end{array}$ & $\begin{array}{l}-1.5835 \\
(0.3186)\end{array}$ & $\begin{array}{l}-0.3110 \\
(0.0682)\end{array}$ \\
\hline & Total & $\begin{array}{l}-0.2785 \\
(0.0695)\end{array}$ & $\begin{array}{l}-0.2703 \\
(0.0696)\end{array}$ & $\begin{array}{l}-0.0197 \\
(0.0778)\end{array}$ & $\begin{array}{l}-1.3293 \\
(0.3172)\end{array}$ & $\begin{array}{l}-0.3240 \\
(0.0698)\end{array}$ \\
\hline \multirow[t]{3}{*}{41} & Internal & $\begin{array}{l}-0.0028 \\
(0.0010)\end{array}$ & $\begin{array}{l}-0.0030 \\
(0.0011)\end{array}$ & $\begin{array}{l}-0.0106 \\
(0.0022)\end{array}$ & $\begin{array}{c}0.0649 \\
(0.0268)\end{array}$ & $\begin{array}{l}-0.0016 \\
(0.0010)\end{array}$ \\
\hline & External & $\begin{array}{l}-0.3169 \\
(0.0592)\end{array}$ & $\begin{array}{l}-0.3051 \\
(0.0596)\end{array}$ & $\begin{array}{c}0.0199 \\
(0.0690)\end{array}$ & $\begin{array}{l}-3.0849 \\
(0.6415)\end{array}$ & $\begin{array}{l}-0.3683 \\
(0.0596)\end{array}$ \\
\hline & Total & $\begin{array}{l}-0.3197 \\
(0.0593)\end{array}$ & $\begin{array}{l}-0.3081 \\
(0.0598)\end{array}$ & $\begin{array}{c}0.0093 \\
(0.0690)\end{array}$ & $\begin{array}{l}-3.0199 \\
(0.6368)\end{array}$ & $\begin{array}{l}-0.3699 \\
(0.0597)\end{array}$ \\
\hline \multirow[t]{3}{*}{42} & Internal & $\begin{array}{l}-0.0003 \\
(0.0001)\end{array}$ & $\begin{array}{l}-0.0003 \\
(0.0001)\end{array}$ & $\begin{array}{l}-0.0009 \\
(0.0002)\end{array}$ & $\begin{array}{c}0.0041 \\
(0.0018)\end{array}$ & $\begin{array}{l}-0.0001 \\
(0.0001)\end{array}$ \\
\hline & External & $\begin{array}{l}-0.3021 \\
(0.0590)\end{array}$ & $\begin{array}{l}-0.2904 \\
(0.0595)\end{array}$ & $\begin{array}{l}-0.0337 \\
(0.0650)\end{array}$ & $\begin{array}{l}-2.1563 \\
(0.4344)\end{array}$ & $\begin{array}{l}-0.3562 \\
(0.0595)\end{array}$ \\
\hline & Total & $\begin{array}{l}-0.3024 \\
(0.0591)\end{array}$ & $\begin{array}{l}-0.2907 \\
(0.0595)\end{array}$ & $\begin{array}{l}-0.0346 \\
(0.0650)\end{array}$ & $\begin{array}{l}-2.1522 \\
(0.4341)\end{array}$ & $\begin{array}{c}-0.3563 \\
(0.0595)^{\circ}\end{array}$ \\
\hline
\end{tabular}


Table 9: Harginal Benefits of Total Rublicly Funded R\&D

(1982 Values; Stand. Error in Parenthesis)

Code

20

26

28

29

30

32

33

34

35

36

37

38

40

41

42
Total

Marginal Benefit

0.0933

$(0.0250)$

0.0306

$(0.0079)$

0.0774

(0.0182)

0.0569

$(0.0207)$

0.0257

(0.0054)

0.0134

$(0.0049)$

0.0142

$(0.0124)$

0.0358

(0.0124)

0.1080

(0.0191)

0.0815

$(0.0156)$

0.0785

$(0.0241)$

0.0234

$(0.0047)$

0.0555

$(0.0139)$

0.0500

$(0.0093)$

0.0341

$(0.0067)$ 
Table 10: The Effect of Reduction of RAD Tax Incentives and Increase of Total Publicly Plnanced R\&D

(In Billions of 1988 dollars)

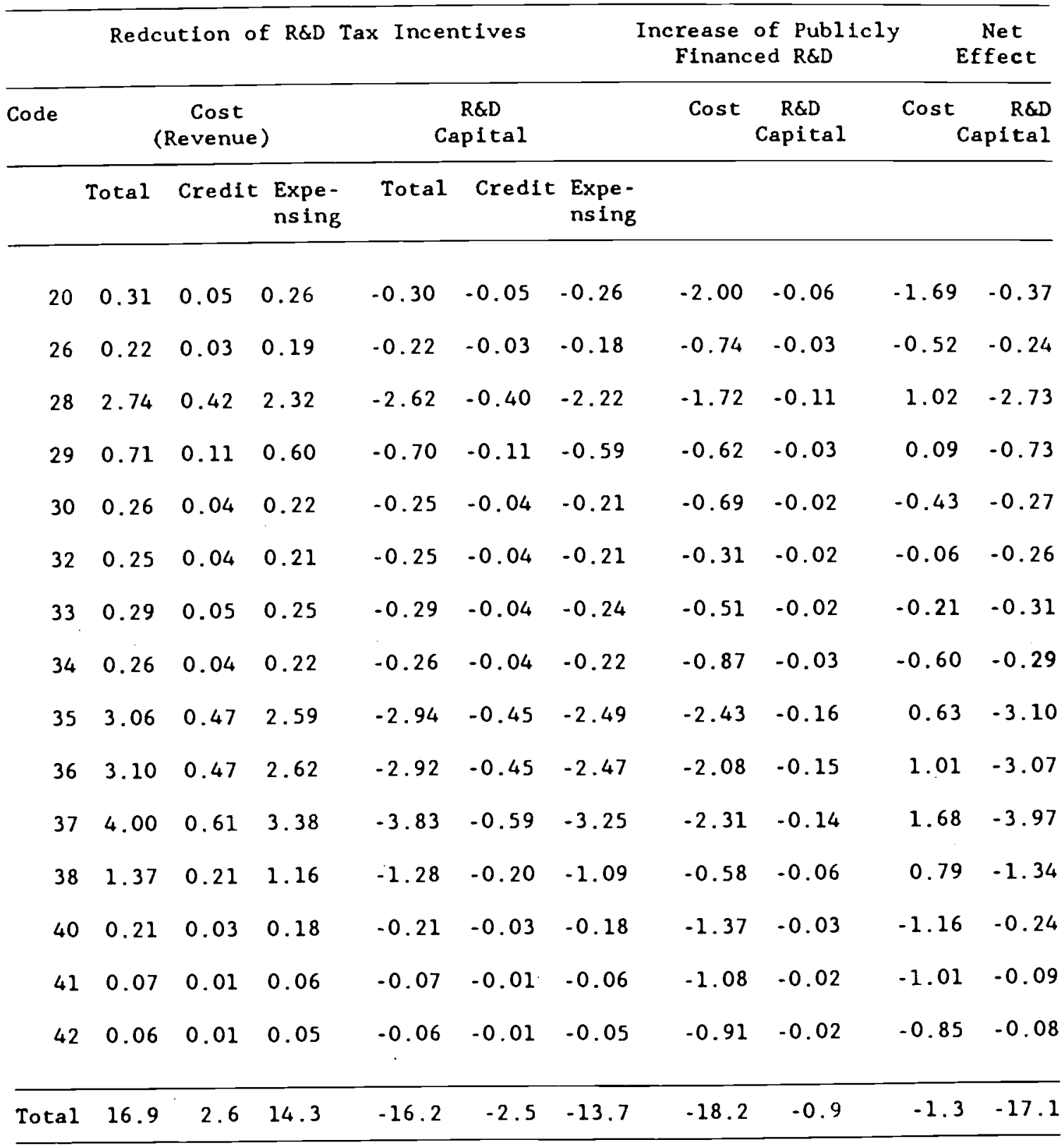

